Discussion Paper No. 13-019

\title{
Innovation, Employment Growth, and Foreign Ownership of Firms - A European Perspective
}

Bernhard Dachs and Bettina Peters

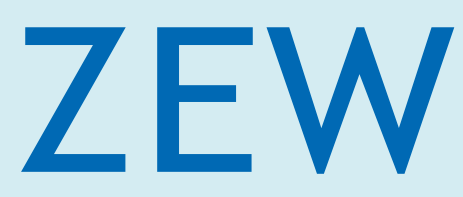

Zentrum für Europäische Wirtschaftsforschung $\mathrm{GmbH}$ Centre for European Economic Research 
Discussion Paper No. 13-019

\title{
Innovation, Employment Growth, and Foreign Ownership of Firms - A European Perspective
}

\author{
Bernhard Dachs and Bettina Peters
}

Download this ZEW Discussion Paper from our ftp server:

http://ftp.zew.de/pub/zew-docs/dp/dp13019.pdf

Die Discussion Papers dienen einer möglichst schnellen Verbreitung von neueren Forschungsarbeiten des ZEW. Die Beiträge liegen in alleiniger Verantwortung der Autoren und stellen nicht notwendigerweise die Meinung des ZEW dar.

Discussion Papers are intended to make results of ZEW research promptly available to other economists in order to encourage discussion and suggestions for revisions. The authors are solely responsible for the contents which do not necessarily represent the opinion of the ZEW. 


\section{Non-Technical Summary}

Subsidiaries of foreign multinational enterprises (MNEs) are among the top performers of research, development and innovation in many EU and non-EU countries. In some small European countries - examples are Austria, Belgium, the Czech Republic, Hungary or Ireland

- foreign-owned firms even account for more than $50 \%$ of total business expenditure for R\&D.

The high relevance of foreign ownership for technology and innovation policy calls for a sound understanding of the innovation behaviour of foreign-owned firms and its impact on economic performance. Using the theoretical model of Harrison, Jaumandreu, Mairesse and Peters (2008), this paper contributes to the existing literature by disentangling sources of employment growth by ownership, and it particularly investigates the role product and process innovation play for employment in foreign-owned and domestically owned firms. We examine the link between innovation and employment using a large data set (Community Innovation Surveys CIS4) of more than 64,500 firms from 16 European countries.

Previous studies have shown that innovation and technology are key dimensions in which foreign-owned and domestically owned firms differ. There is ample evidence that MNEs tend to possess superior firm-specific assets, operate more frequently in $\mathrm{R} \& \mathrm{D}$-intensive sectors and employ more highly-qualified staff than domestically owned firms. Both groups also differ in their capabilities to create new products and in their ability to successfully introduce innovations to the market. Our analyses enlighten that these differences, in turn, lead to differences in employment creation and destruction from innovation between the two groups.

We find that foreign-owned firms experience higher employment losses than domestically owned firms due to general (non-innovation related) productivity improvements and in manufacturing also partly due to process innovation. A likely explanation for this finding is that foreign-owned firms that introduce new processes adopt superior technologies of their parent companies. In addition and in contrast to domestic firms, most foreign-owned firms are able to produce new products with a higher efficiency than existing products (except for European FOF in manufacturing). These larger productivity gains might be worrying as they imply that foreign-owned firms would need to create much more jobs with product innovation and existing products to meet the employment growth rate of domestically owned firms. Taking direct and indirect demand effects into account, our analysis reveals that the net contribution of product innovation to employment is positive, and it is indeed higher for foreign-owned firms than for domestic firms. This is primarily due to higher sales growth rates with new products which are likely to result from learning effects and larger market 
power. Together with the positive employment effect stemming from sales growth with old products, this leads in sum to an increase in employment in foreign-owned firms. However, it does not reach the employment growth figures for domestically owned firms. 


\section{Das Wichtigste in Kürze}

Unternehmen im ausländischen Eigentum zählen in vielen Ländern zu den wichtigsten Akteuren in Forschung, Entwicklung und Innovation. In einigen kleinen europäischen Staaten wie Belgien, Österreich oder der Tschechischen Republik beträgt ihr Anteil an den F\&EAusgaben des Unternehmenssektors bereits mehr 50\%.

Diese prominente Rolle hat in den letzten Jahren gerade auch im Bereich der Innovations- und Technologiepolitik das Interesse an den Innovationsprozessen ausländischer Unternehmen und deren Auswirkungen auf die ökonomische Performance beflügelt. Basierend auf einem theoretischen Modell von Harrison, Jaumandreu, Mairesse und Peters (2008) identifiziert die vorliegende Studie die Quellen des Beschäftigungswachstums von in- und ausländischen Unternehmen und geht dabei insbesondere der Frage nach, welche Rolle Produkt- und Prozessinnovationen für die Beschäftigungsentwicklung in beiden Unternehmenstypen spielen. Grundlage der empirischen Untersuchung ist die vierte Innovationserhebung der Europäischen Union (CIS 4) mit rund 64.500 Firmenbeobachtungen aus 16 Ländern.

Bisherige Studien haben gezeigt, dass firmenspezifische Vermögenswerte ein wesentliches Merkmal sind, in denen sich in- und ausländische Unternehmen unterscheiden. So sind multinationale Unternehmen (MNE) häufig im Besitz besonders überlegener firmenspezifischer Vermögenswerte wie Wissen, Produktionstechnologien, Vertriebskanäle, Netzwerke oder Managementfähigkeiten. Darüber hinaus unterscheiden sich beide Gruppen auch in ihren Fähigkeiten neue Produkte zu entwickeln und erfolgreich auf dem Markt einzuführen. Unsere Studie kommt zu dem Ergebnis, dass sich diese Unterschiede auch in unterschiedlichen Beschäftigungseffekten widerspiegeln.

Firmen, die sich im Besitz einer ausländischen Muttergesellschaft befinden, verbuchen einerseits einen höheren Beschäftigungsabbau auf Grund von größeren Produktivitätsgewinnen in der Herstellung existierender Produkte, die nicht auf eigene Prozessinnovationsaktivitäten zurückzuführen sind. Diese können z.B. das Resultat von Lerneffekten, besser ausgebildetem Personal oder organisatorischen Veränderungen sein. Gleichzeitig realisieren ausländische Unternehmen im verarbeitenden Gewerbe auch stärkere Produktivitätsgewinne durch Prozessinnovationen. Darin dürfte zum Ausdruck kommen, dass ausländische Töchterunternehmen die Möglichkeit haben, die überlegeneren Produktionstechnologien ihrer Muttergesellschaften zu übernehmen. Darüber hinaus und im Gegensatz zu heimischen Unternehmen zeigt sich, dass in zahlreichen ausländischen Unternehmen neue Produkte mit einer höheren Arbeitsproduktivität als alte Produkte hergestellt werden (Ausnahme: Unternehmen mit europäischen Muttergesellschaften im verarbeitenden 
Gewerbe). Diese größeren Produktivitätsgewinne könnten Anlass zur Sorge geben, da sie implizieren, dass ausländische Unternehmen mehr Arbeitsplätze durch Produktinnovationen und Nachfrage nach existierenden Produkten schaffen müssen, wenn sie das gleiche Beschäftigungswachstum wie heimische Unternehmen generieren sollen. Berücksichtigt man die direkten und indirekten Nachfrageeffekte, die mit Produktinnovationen verbunden sind, dann ergeben unsere Analysen, dass der Nettobeschäftigungsbeitrag der Produktinnovationen in ausländischen Unternehmen in der Tat positiv und größer als in heimischen Unternehmen ist. Dies lässt sich vor allem auf ein höheres Umsatzwachstum mit neuen Produkten zurückführen. Zusammen mit dem Beschäftigungswachstum aufgrund von Änderungen in der Nachfrage nach den existierenden Produkten, ergibt sich in der Summe aller Teileffekte ein positives Beschäftigungswachstum in ausländischen Unternehmen. Dieses blieb jedoch zumindest in der betrachteten Zeitperiode hinter dem Beschäftigungswachstum in heimischen Unternehmen zurück. 


\title{
Innovation, Employment Growth, and Foreign Ownership of Firms
}

\author{
A European Perspective \\ Bernhard Dachs ${ }^{\mathrm{a})}$ and Bettina Peters ${ }^{\mathrm{b})}$
}

April 2013

\begin{abstract}
:
This paper examines how foreign-owned and domestically owned firms transform innovation into employment growth. The empirical analysis, based on the model of Harrison, Jaumandreu, Mairesse and Peters (2008) and CIS data for 16 countries, reveals important differences between the two groups: Due to general productivity increases and process innovation, foreign-owned firms experience higher job losses than domestically owned firms. At the same time, employment- creating effects of product innovation are larger for foreignowned firms. Together with employment-stimulating effects stemming from existing products, they overcompensate the negative displacement effects resulting in net employment growth in foreign-owned firms. However, net employment growth turns out to be smaller in foreign-owned firms than in domestically owned firms.
\end{abstract}

JEL classification: O310; O330; F230

Keywords: employment; innovation; foreign ownership; Community Innovation Survey; host country effects

a) AIT Austrian Institute of Technology, Donau-City-Strasse 1, A-1220 Vienna, Austria. Email: bernhard.dachs@ait.ac.at, T +43 (0) 50 550-4563, F +43 (0) 50 550-4599

b) Centre for European Economic Research (ZEW), Mannheim, Germany, Mannheim Centre for Competition and Innovation (MaCCI) and University of Zurich, Switzerland. Email: b.peters@zew.de, T +49 (0) 621 1235-174, F +49 (0) 621 1235-170

\section{ACKNOWLEDGEMENTS}

The authors thank Sergiu-Valentin Parvan from EUROSTAT for data access and his support. We also thank Dirk Czarnitzki (KU Leuven), Joao Liborio (European Commission, DG Enterprise), Christian Rammer (ZEW), and Torben Schubert (Lund University) for their valuable comments. Part of the work was done within the European 
Commission project B2/ENTR/05/091-FC and was financed under the Competitiveness and Innovation Framework Programme (CIP) which aims to encourage the competitiveness of European enterprises. Support by the European Commission in the collection, analysis and interpretation of the data is gratefully acknowledged. We furthermore thank participants at the ZEW conference on Innovation and Patenting (Mannheim 2011), EARIE (Stockholm 2011), IIOC (Washington 2012) and DRUID (Copenhagen 2012) conferences for valuable comments. All errors remain those of the authors.

An overview of third-party funded projects Bettina Peters was involved in is published on her personal web site: http://www.zew.de/de/mitarbeiter/mitarbeiter.php3?action=mita\&kurz=bpe 


\section{INTRODUCTION}

The effects of globalisation on employment are a key issue in policy debates. Foreign-owned firms can be a source of employment growth in their host countries (Barba Navaretti, 2004; Bellak, 2004). Foreign-owned firms are affiliates owned by another company (the parent company of the affiliate) headquartered in a foreign country. Their market entrance and subsequent growth create new labour demand. Furthermore, foreign-owned firms may have access to new technologies provided by their parent company which increase their competitiveness and, as a result, also their demand for labour. In addition, knowledge and technologies might spill over to domestically owned firms and stimulate their growth as well. But the presence of foreign-owned firms may also have negative consequences for employment. Growth may be lower because foreign-owned firms may be able to exploit synergy effects within the company group. Compared to domestically-owned firms, employment in foreign-owned firms may also be more volatile (Scheve and Slaughter, 2004; Buch and Lipponer, 2010).

This paper wants to contribute to this discussion by disentangling the sources of employment growth in domestically owned and foreign-owned firms. We start from two basic assumptions discussed in more detail below. First, innovation and technology are major drivers for employment growth of firms (Bogliacino and Pianta, 2010; Harrison et al., 2008; Pianta, 2005). Second, innovation and technology are also key dimensions in which foreign-owned and domestically owned firms differ. There is ample evidence that multinational enterprises (MNEs) tend to possess superior firm-specific assets, operate more frequently in R\&Dintensive sectors and employ more highly-qualified staff than domestically owned firms (Bellak, 2004; Griffith and Simpson, 2004; Markusen, 2002). Both groups also differ in their capabilities to create new products and in their ability to successfully introduce innovations to the market (Dachs et al., 2008; Frenz and Ietto-Gillies, 2007; Sadowski and SadowskiRasters, 2006). We will hypothesize that these differences, in turn, lead to differences in employment creation and destruction from innovation between the two groups. To give two examples: Foreign-owned firms that introduce new processes by adopting superior technologies of their parent companies might achieve higher productivity gains and thus less employment growth. On the other hand they might reach higher sales and employment growth rates when introducing new products because they can learn from experiences the multinational company has made in other countries. 
We investigate the linkage between employment growth and innovation in foreign-owned and domestically owned firms. The paper differs in three important points from other contributions: First, we employ an econometric model that examines the effects of process innovation and output growth from product innovation on employment at the firm level. This approach allows us to disentangle some of the employment effects at work and to relate differences in employment creation between foreign-owned and domestically owned firms to differences in innovation behaviour. This is in contrast to most studies in this area which focus on indirect employment effects in domestic firms due to spillovers that arise from to the presence of foreign-owned firms (Keller, 2010; Marin and Sasidharanb, 2010; Motohashi and Yuan, 2010). Second, unlike other studies, we do not focus on one country but scrutinize employment effects at the firm level using a large data set containing observations from 16 European countries. Finally, we provide a separate analysis for the service sector. The service sector is a major source of employment growth in industrialized countries (O'Mahony and Timmer, 2009). Studies that investigate innovation as well as multinational activities, however, often neglect service industries. ${ }^{1}$

The paper is organized as follows: Chapter 2 discusses theoretical linkages between innovation and employment in foreign-owned and domestically owned firms from which we draw our hypotheses presented in chapter 3. Chapter 4 describes the data set. We start our empirical analysis with descriptive statistics on employment growth and innovation for both groups of firms in chapter 5. Chapter 6 explores the econometric set-up of this study and chapter 7 presents and discusses the results. Chapter 8 draws conclusions from the analysis.

\section{BACKGROUND}

Our research draws on two strands of literature: The first strand investigates employment impacts of innovation, and the second one deals with differences between foreign-owned and domestically owned firms in general and in innovation in particular.

\subsection{Innovation, job creation and job destruction}

Innovation and employment are related through various channels, and different forms of innovation may have different effects on employment growth (Garcia et al., 2004; Hall et al.,

1 An early study which investigates the employment effects of innovation in services is Evangelista and Savona (2003). They find different effects between various sectors, firm size classes and skill levels of the employees. Recent studies that include service industries are Harrison et al. (2008), Hall et al. (2008) and Peters (2008). All these papers study the employment effect of innovation activities for service firms in general without distinguishing between ownership of firms. 
2008; Harrison et al., 2008; Pianta, 2005). A basic distinction is between product and process innovation. Both kinds of innovation can be associated with labour-saving effects which reduces employment (called displacement effects) and employment-stimulating effects (called compensation effects) (see Table 1).

Table 1: Effects of product and process innovation on employment at the firm level

\begin{tabular}{|l|l|l|}
\hline & $\begin{array}{l}\text { Employment-reducing effects } \\
\text { (Displacement effects) }\end{array}$ & $\begin{array}{l}\text { Employment-creating effects } \\
\text { (Compensation effects) }\end{array}$ \\
\hline $\begin{array}{l}\text { Product } \\
\text { innovation }\end{array}$ & $\begin{array}{l}\text { Productivity effect of product innovation: } \\
\text { New products require less (or more) } \\
\text { labour input (-) } \\
\begin{array}{l}\text { Indirect demand effect: } \\
\text { Decrease in demand of existing } \\
\text { substitutes (-) }\end{array}\end{array}$ & $\begin{array}{l}\text { Direct demand effect: } \\
\text { New products increase overall demand (+) } \\
\text { Indirect demand effect: } \\
\text { Increase in demand of existing } \\
\text { complementary products (+) }\end{array}$ \\
\hline $\begin{array}{l}\text { Process } \\
\text { innovation }\end{array}$ & $\begin{array}{l}\text { Productivity effect of process innovation: } \\
\text { Less labour input for a given output (-) }\end{array}$ & $\begin{array}{l}\text { Price effect: } \\
\text { Cost reduction passed on to price expands } \\
\text { demand }(+)\end{array}$ \\
\hline
\end{tabular}

The link between innovation and employment can be analysed at different levels: firm, sector, and macro level. This paper takes a firm-level perspective, representing one of the main instances where the according mechanisms are more or less explicitly supposed to work (Harrison et al., 2008). At the firm-level, employment effects of process innovation are closely related to productivity changes. The introduction of new production processes most often leads to an increase in productivity since process innovation allows firms to produce the same amount of output with less labour input and, ceteris paribus, lower unit costs. The extent of this negative displacement effect, also called productivity effect, depends on the current production technology and, thus, the rate of substitution between input factors as well as on the direction of the technological change.

At the same time, the reduction in unit costs allows the innovative firm to lower its product price. In a dynamic perspective, lower prices can lead to a higher demand for the product, thus increasing output. The magnitude of this positive compensation effect, also called price effect, depends on the price reduction, the price elasticity of demand, the degree of competition as well as on the behaviour and relative strength of different agents such as managers and unions within the firm (Garcia et al., 2004).

Product innovation spurs employment growth mainly via demand. When a new product has successfully been introduced to the market, it creates new demand for the output of the 
innovating firm. This direct demand effect can either be the result of an overall market expansion, or it may come at the expense of the firm's competitors. The size of the compensation effect resulting from demand increases depends on the existence of substitutes and the reactions of competitors (see Garcia et al., 2004).

In addition to the direct demand effect, various indirect employment effects from product innovation may occur at the firm level as well. First, indirect demand effects on the innovative firm's existing products have to be taken into account. If the new product (partially or totally) replaces the old one, labour demand for the production of the old product will decrease, and the overall effect is ambiguous for the innovating firm. However, in the case of complementary demand relationships, the new product will cause demand for existing products to rise as well, and employment will increase further. Second, the same amount of output of the new product may be produced at higher or lower productivity levels compared to the old product. That is, the new product may imply a change in production methods and input mix, which could either reduce or increase labour input (Harrison et al., 2008). This productivity effect of product innovation thus could also lead to an employment reduction, even if product innovation is not associated with simultaneous process innovation. The extent and direction of this effect has to be determined empirically.

On a sector or macro level, additional employment effects of innovations exist. Process innovations, for instance, may impact employment in upstream firms. It is directly stimulated if the innovating firm acquires new machines in order to improve its production process. Indirect effects may arise if the innovative firm is able to increase its output. Supplier firms benefit from this output increase and may boost their labour demand as well. On the other hand, competitors which cannot keep pace with the technological progress will lose market share or even disappear, implying a deterioration of jobs. Production innovations may also cause positive or negative externalities to other firms in the same or in other industries. The extent of these indirect demand effects in other firms heavily depends on the demand relationships. While the innovating firm in principle may face an unlimited demand, demand is usually constrained at the industry level. Product innovation creates thus negative externalities if the innovating firm expands production at the expense of other firms' existing products. At the sector and macro level, these indirect demand effects on existing products, which are known as 'business stealing' in the literature (Aghion and Howitt, 1992, p. 338) have to be taken into account. In the case of complementary demand, however, product 
innovation will stimulate demand for existing products of other firms as well. It may even trigger the development of new complementary products.

As already mentioned, this paper takes a firm-level perspective. However, as we will explain in more detail in section 6, the model employed captures indirect demand effects such as business stealing that are caused by product or process innovations of other firms - at least for surviving firms. Therefore, it partly accounts for effects working at the sector or macro level. However, we won't be able to draw a complete picture at the macro level since we have no information on employment changes due to firm entries and exits in the data set.

The majority of empirical firm-level studies find a positive relationship between product innovation and employment growth in manufacturing (Blechinger et al., 1998; Chennells and Van Reenen, 2002; Entorf and Pohlmeier, 1990; Garcia et al., 2004; Greenan and Guellec, 2000; Hall et al., 2008; Harrison et al., 2008; König et al., 1995; Rottmann and Ruschinski, 1998; Smolny, 1998, 2002; Van Reenen, 1997). ${ }^{2}$ Empirical evidence on the employment effects of process innovations is less clear than for product innovation. In the studies of Van Reenen (1997) and Entorf and Pohlmeier (1990), the impact of process innovations turns out to be small and not significant at all. König et al. (1995), Smolny and Schneeweis (1999), Smolny (2002), Greenan and Guellec (2000) or Lachenmaier and Rottmann (2011), in contrast, report a significant positive effect of process innovation on employment growth. The latter two studies even establish that process innovation create more new employment at the firm level than product innovation. Contrarily, Blechinger and Pfeiffer (1999) find evidence of labour displacement by process innovation, the effect being more pronounced in larger firms.

\subsection{Innovation, employment growth and foreign ownership}

Displacement and compensation effects of innovation may differ between foreign-owned and domestically owned firms because both groups vary in important characteristics related to product and process innovation.

A first important difference refers to firm-specific innovation capabilities. Foreign-owned firms often possess superior firm-specific assets such as knowledge, technologies, brands or distribution networks which domestically owned firms may not have at their disposal (Caves, 1996 (1974), Dunning, 1981; Helpman et al. 2004; Markusen, 2002). These assets also

2 For empirical evidence about the role of demand patterns and different types of innovation on employment at the macroeconomic and sectoral level, see for instance, Vivarelli and Pianta (2000). 
include organisational and managerial capabilities and practices (Bloom and Van Reenen, 2010).

Firm-specific assets can be transferred from the parent company to its affiliates. In addition, MNE affiliates are embedded in intra-firm networks of knowledge exchange (Gupta and Govindarajanan, 2000; Williams and Lee, 2009; Zanfei, 2000) and benefit from the exchange between MNE affiliates in different countries. Learning from the experiences of the parent company and MNE subsidiaries in other countries gives foreign-owned affiliates an advantage when it comes to developing and introducing product and process innovation. A new superior production technology of the parent company, for example, may be beneficial for the foreign affiliate as well. Firm-specific assets may further allow the affiliate to develop own innovations based on existing technologies which may lower development costs. Moreover, foreign-owned firms may be able to introduce new products more successfully into the market and reap higher sales growth from new products which in turn translate into a higher employment growth from product innovation because they can benefit from the experiences the MNE made in other countries with similar products and technologies. Firms which are not part of a corporate group lack of these advantages.

Second, large firms, in particular multinationals, can spread risks over a larger number of projects, have considerable internal funds for innovation and easier access to external finance for risky innovation projects, and may benefit from a higher degree of specialisation and a more elaborated division of labour in research, development and innovation, which is not feasible in smaller firms.

In addition, the likelihood of engaging in international production increases if a company enjoys substantial market power given by the ownership of products or production processes (Dunning 1980). Its foreign-owned affiliates - as part of the multinational group - are likely to partake in this market power. Differences in market power in turn lead to differences in the price setting behaviour of firms in general and in the course of product and process innovation activities in particular. The implications with respect to the innovation-employment link are mixed. Firms endowed with market power can withhold a larger proportion of the cost reduction. Hence, one might expect a stronger negative impact of process innovations in foreign-owned firms. But market power is also important for the size of the demand effect of product innovation. Two countervailing effects might arise. One the one hand, firms that enjoy substantial market power are likely to set higher prices for new products and thus dampen positive demand and employment effects (Garcia et al. 2004). On the other hand, they 
might be more successful in stealing business from their competitors. Substantial market power might also prolong the time in which competitors react to the introduction of product innovation.

Various studies have evaluated differences in innovation between foreign-owned and domestically owned firms empirically (Dachs et al., 2008; Ebersberger et al., 2005; Sadowski and Sadowski-Rasters, 2006). These studies find a higher innovation output of foreign-owned firms in terms of sales from new products after controlling for firm characteristics. Innovative input (such as expenditure on R\&D and other innovation-related activities), in contrast, is similar or lower for foreign-owned firms. Hence, superior assets may encourage foreignowned firms to invest less in R\&D relative to domestically-owned firms (Un and CuervoCazurra, 2008).

\section{HYPOTHESES}

We hypothesize that the differences between foreign-owned and domestically owned firms discussed above translate into differences in displacement and compensation effects and different labour market outcomes of the two groups.

Labour market outcomes of product innovation consist of three components: direct demand effects, productivity effects and indirect demand effects.

1) Following the literature, we assume that foreign-owned firms enjoy higher sales from product innovation because they can make use of superior assets for their innovation activities, and benefit from the experiences with the market introduction of these products in other countries. Furthermore, being part of a multinational group may imply larger market power making it easier for foreign-owned firms to steal business and more difficult for domestic competitors to react and to erode innovation benefits of foreign-owned firms. On the other hand market power might dampen the direct demand effect. Garcia et al. (2004) find the net effect to be positive. Hence, we expect the direct demand effect and thus the job creation from new products to be larger for foreign-owned firms (H1a).

2) New products may be produced with higher efficiency than old products. We expect this productivity effect of product innovation and thus the job destruction due to shifts in labour input to be larger for foreign-owned firms since they can benefit from superior production technologies and learning effects within the company group (H1b). 
3) The indirect demand effect of new products on existing products depends on the degree of complementarity between the new and the old product. The literature provides no clear evidence whether product innovation of foreign-owned and domestically owned firms differ in this respect. However, in small firms with just one or a few products it is more likely that new products will replace existing ones due to capacity constraints. Hence, we suppose that the indirect employment effect due to shifts in demand for existing products is larger for foreign-owned firms (either a less negative displacement or stronger positive compensation effect; H1c).

In general, the overall employment effect of product innovation is ambiguous. Empirical evidence from other studies (see section 2.1), however, has demonstrated that the compensation effect often outweighs the displacement effect of product innovation. We therefore expect a positive link between product innovation and employment growth, which should be stronger for foreign-owned firms:

H1: Foreign-owned firms enjoy a higher employment growth from product innovation than domestically owned firms.

The overall employment impact of process innovation is likewise the combination of two factors: productivity and price effect. We suppose that foreign-owned firms, on average, enjoy higher productivity gains from new production processes than domestically owned firms, because they benefit from internal technology transfer and learning effects in the corporate network between affiliates and the parent company. This will lead to less labour input for a given output, and thus larger displacement effects from process innovation (H2a). Foreignowned firms as part of a multinational group may also be less inclined to pass on price reductions because of their larger market power which would imply smaller compensation effects (H2b). Combining both effects, we either expect stronger job destruction or less job creation from process innovation in foreign-owned firms.

H2: Foreign-owned firms face either higher employment losses or smaller employment growth from process innovation than domestically owned firms.

The advantages of size, exchange in a multinational network and market power are not restricted to foreign-owned firms alone. Some of these advantages are also shared by domestically owned firms which are part of a (multinational) enterprise group themselves. Hence, parts of the literature argue that the decisive firm characteristic is not foreign 
ownership as such, but multinationality, a feature which is shared by domestic and foreignowned multinational firms (Bellak, 2004; Dachs et al., 2008; Frenz and Ietto-Gillies, 2007). Bellak and Pfaffermayr (2000), for example, examine performance gaps in sales and employment growth, export and investment propensity between foreign-owned and domestically owned firms in Austria. They find that domestic and foreign multinationals perform rather similarly and that both groups perform better than purely national firms. We can therefore assume that domestically owned group firms (which may also be multinationals) are more similar to foreign-owned firms than to unaffiliated domestically owned firms.

H3: Differences in employment effects between foreign-owned firms and domestically owned group firms are smaller than between foreign-owned firms and domestically owned unaffiliated firms.

There is also reason to assume that there are differences between foreign-owned firms of different home countries. First, because there are productivity differences between countries which may result in different endowments of foreign-owned firms with technology and management capabilities and different productivity levels between foreign-owned firms. Moreover, the subsidiary is embedded in the norms, values and habits of its corporate group which are shaped by the home country. One example for such differences is the 'time horizon’ of agents (Drejer, 2000; Lundvall, 1998): the Anglo-Saxon systems are characterised by a shorter time horizon in corporate governance than the Japanese and German systems, which are known for working with a quite long time horizon in investment decisions. Another potential source of variation between foreign-owned firms of different home countries are differences in legal systems, accounting standards and codes of corporate governance between the home and host country (Buckley, 2000, p 297).

Evidence for differences between foreign-owned firms of different home countries provide, amongst others, Harris and Robinson (2003) who examine employment growth in 20 UK manufacturing industries over the period 1974-1995. Their results indicate that US owned plants performed better than domestic ones in most industries. For six industries they found no significant differences in performance, while domestically owned firms performed better in two industries. EU-owned plants outperformed domestically owned plants in only four industries. The evidence for other home countries (i.e. old commonwealth countries, South East Asian countries, and the rest of the world) was mixed, with foreign-owned firms performing better in some industries, but worse in others. Similarly, Oulton (1998) reports a 
productivity advantage of US affiliates compared to UK-owned establishments, but finds no difference between non-US foreign-owned establishments and UK-owned establishments. Globerman et al. (1994) and Bellak and Pfaffermayr (2000), in contrast, find no differences related to home countries.

H4: There are differences between foreign-owned firms in employment creation and destruction which are related to different home countries of foreign-owned firms.

\section{DATA SET}

We employ data from the Community Innovation Survey (CIS) to estimate employment effects of innovation activities in foreign-owned and domestically owned firms. The CIS is a survey based on a harmonised questionnaire developed by Eurostat. It is conducted by national statistical offices or research institutes in all EU member states, Iceland and Norway. The CIS aims at assessing various aspects of the innovative behaviour and performance of enterprises and follows the definitions laid down in the OECD Oslo Manual (OECD, 2005). EUROSTAT provides access to CIS micro data at the firm level at their premises. We use the CIS 4 sample which refers to the period 2002-2004. The sample used for this analysis includes more than 64,600 firms from 16 European countries. It comprises of 8 West (Denmark, Spain, France, Greece, Italy, Luxemburg, Norway and Portugal, 40,600 observations) and 8 East European countries (Bulgaria, Czech Republic, Estonia, Hungary, Latvia, Romania, Slovenia and Slovakia). ${ }^{3}$ The distribution of firms by country and industry is provided in Tables A1 and A2 in the Annex.

In addition to data on sales and employment and various innovation indicators for 2002 and 2004, the CIS data contains information on whether the firm is part of an enterprise group. The questionnaire furthermore asks for the country of origin of the parent company, i.e. the country where the headquarters of the enterprise group is located. Based on these two items we distinguish the following types of foreign and domestic ownership (Figure 1):

\footnotetext{
3 Data for Sweden, Iceland, Finland and Lithuania could not be used due to missing information for some of the variables used in this analysis.
} 
Figure 1: Types of domestic and foreign ownership in the CIS data

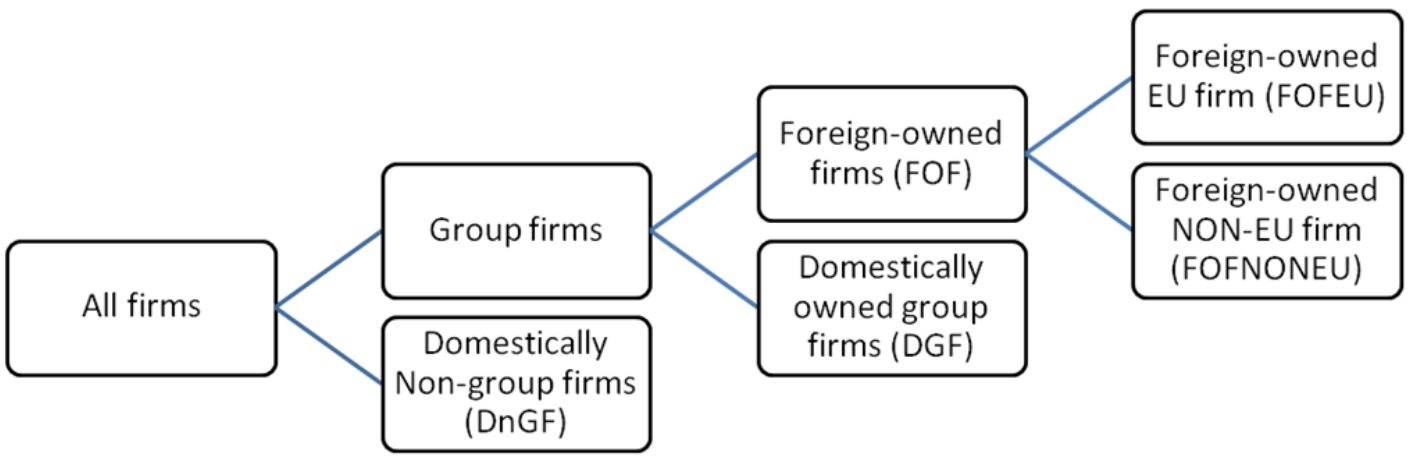

Source: Own illustration

We further distinguish between foreign-owned firms from different home countries: Foreignowned European firms (FOFEU) belong to an enterprise group with a parent company located in another European country. An example is a French firm whose parent company is located in Spain. Foreign-owned non-European firms (FOFNONEU) are part of an enterprise group with a parent company located outside Europe. An example is a firm domiciled in France with a parent company from the US. The group of FOFNONEU is further split into foreign-owned US firms (FOFUS) and foreign-owned non-European firms from the rest of the world (FOFROW).

As we will explore in more detail in section 6, prices are an important piece of information for disentangling different employment impacts. Like most other firm-level data sets, the CIS does not contain information on prices at the firm level. Instead, we employ producer price index data provided by EUROSTAT (time series DS-074564-industry) at three-digit level for NACE 15.9, NACE 24.4, and NACE 36.1, and at two-digit level for all other industries. We use the EU average price movements at the industry level measured by the producer price index for countries where no producer price index is available (in particular for SK, PT, LU, LV, EE). Due to lack of data, we apply the average producer price index for the production sector also for the service sector. 


\section{DESCRIPTIVE STATISTICS}

A breakdown of the sample according to the ownership status reveals that the vast majority of firms are DnGF, followed by DGF (Table A3 in the Annex). DnGF also represent the vast majority of domestically owned firms in the sample $(83 \%$ and $73 \%$ in manufacturing and services, respectively), and results for all domestically owned firms are very similar to the results for DnGF alone.

FOF are the exception in the sample. In general, their share is highest in small countries. Table A3 also indicates that foreign-owned affiliates are more frequent among service firms (9.5\%) than among manufacturing firms (4.9\%). The share of foreign-owned affiliates from Europe exceeds the share of foreign-owned Non-European firms in all countries. ${ }^{4}$

From 2002 to 2004, average employment growth was fastest in the group of DnGF. Employment grew more slowly in FOF than in DnGF, but at least in manufacturing faster in FOF than in DGF (Figure 2 and Table 2). US subsidiary firms had a considerably slower employment growth than the other sub-groups of foreign-owned firms. Figure 2 furthermore confirms the importance of the service sector for creating employment: Employment growth was higher in services than in manufacturing. Foreign-owned service firms, however, exhibited slower employment growth than DnGF and DGF in services. Though not reported here, we see this pattern for all countries.

One should keep in mind that these growth rates are larger than the numbers published by official statistics. This is due to the fact that (i) we can only observe surviving firms, (ii) we restricted the sample to firms with at least 10 employees and excluded certain industries, and (iii) we average the employment growth across firms instead of taking the ratio of the sum of changes in employment for all firms to the sum of employed personnel. ${ }^{5}$ Due to this method, average employment growth rates are influenced more heavily by very fast growing firms. The median employment growth rate, i.e. the employment growth rate experienced by the least 50 per cent of firms, is much lower at $1.9 \%$ in manufacturing and $6.9 \%$ in services.

\footnotetext{
4 The only exception is the manufacturing sector in Greece. All figures are weighted.

5 In order to use the latter definition, one would need employment weights to calculate the total employment figures of the population (total or in subgroup). However, for most countries Eurostat CIS data include only sample weights that extrapolate to the number of firms in each stratum and not to the number of employees.
} 
Figure 2: Employment growth by ownership, manufacturing and services, 2002-2004

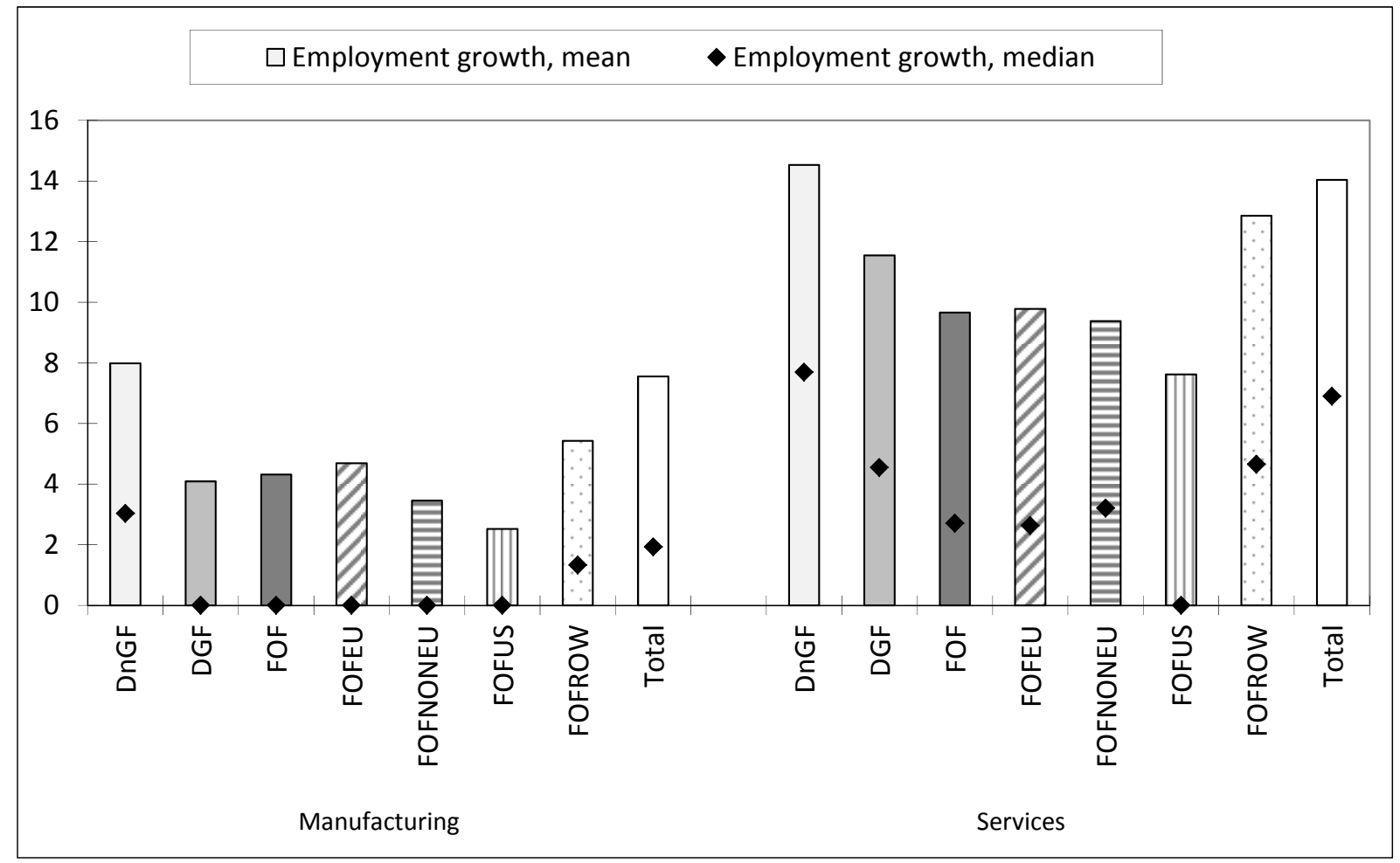

Notes: Weighted figures. Weighting factors are provided by Eurostat.

Source: CIS 4, Eurostat, own calculation.

In addition to employment growth, Table 2 also reports descriptive statistics on innovation behaviour by ownership type. Both DGF and FOF have a higher propensity for product and process innovation than DnGF. This may reflect differences in innovation capabilities due to knowledge and technology transfer within the group but also differences in size. The difference between DGF and FOF is smaller for process than for product innovation, which is more frequent among FOF firms than among DGF and DnGF. Furthermore, the figures confirm our supposition (H1a) of higher sales growth rates due to new products for FOF (13.4\% in manufacturing and $11.6 \%$ in services) than for DnGF (7.1\% and 5.9\%) and DGF (11.7\% and $8.8 \%)$. 
Table 2: Descriptive statistics by ownership type

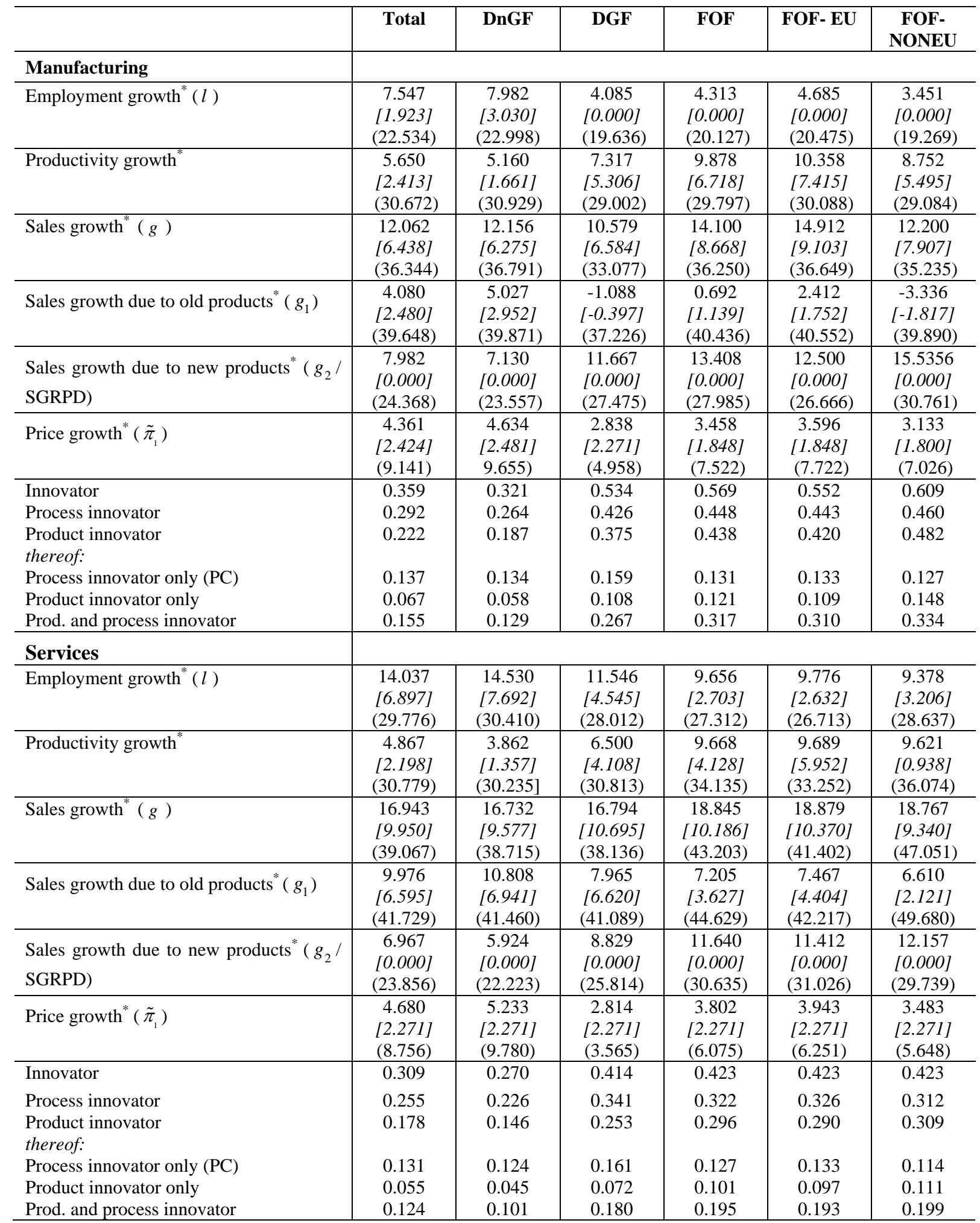

Notes: Weighted figures. Weighting factors are provided by Eurostat. * Figures reported are average growth rates, median growth rates in brackets and standard deviations in parentheses.

Source: CIS 4, Eurostat, own calculation. 


\section{ECONOMETRIC SET-UP}

To investigate employment effects of innovation we employ a model developed by Harrison et al. (2008). A main advantage of this model is that it allows us to disentangle some of the theoretical employment effects mentioned above. Furthermore, it is well-suited for analysing firm-level employment impacts of innovation using the specific information provided by CIS data. In particular, it establishes a theoretical relationship between employment growth and innovation output in terms of sales growth due to new products. The latter can be directly calculated with CIS data. This model has already been used to evaluate employment effects of innovation in a cross-country comparison for the UK, Spain, France and Germany (Harrison et al., 2008), Chile (Benavente and Lauterbach, 2007), and Italy (Hall et al., 2008), as well as to study employment effects of different types of innovation (Peters, 2008). In the following, we briefly sketch the model and refer to Harrison et al. (2008) for more details.

The model is based on a simple multi-product framework. The basic idea is that a firm can produce different products. It is further assumed that one can observe a firm $j$ at two points in time $t(=1,2)$. In $t=1$ the firm produces one or more products which are aggregated to one product which is called the "old product" or "existing product". Between $t=1$ and $t=2$, the firm can decide to launch one or more new or significantly improved products. The new product can (partially or totally) replace the old one if they are substitutes or enhance the demand of the old product in case of complementarity. To produce the different outputs, it is assumed that firms use conventional inputs labour $L$ and capital $C$ (and that the production function is linear homogeneous in these inputs). Moreover, specific efficiencies for the production process of both goods $\theta_{i t}$ and its evolution over time are driven by the knowledge capital of the firm (which is assumed to be a non-rival input).

Based on these assumptions, Harrison et al. (2008) derive the conditional labour demand functions for each product for each point in time and, as a result, the overall employment growth rate: $l=\alpha_{0}+\alpha_{1} p c+y_{1}+\beta y_{2}+u$. Following the theoretical considerations above, employment growth $l$ in the model stems from three different sources: (i) from the efficiency increase in the production of the old product, which negatively affects labour demand and which can be different for non-process innovators $\left(\alpha_{0}\right)^{6}$ and process innovators $p c\left(\alpha_{1}\right)$; (ii) from the rate of change in real output growth of the old product $\left(y_{1}\right)$; and (iii) from starting

\footnotetext{
6 Efficiency gains for non-process innovators may for instance result from organisational innovation, better skilled labour, learning effect or spillover effects.
} 
production of the new product (positive sign). The employment effect of the latter depends on the efficiency ratio between both production technologies $\left(\beta=\theta_{22} / \theta_{11}\right)$ and the real output growth due to new products $\left(y_{2}\right)$. Note that $y_{1}$ combines sundry effects. Output changes in old products are provoked by the new product to a certain degree, the induced change being negative for substitutes and positive for complements. It also captures the effect that is induced by competitors' innovations (business stealing effects) as well as an exogenous increase in demand for old products. Due to data limitations we cannot disentangle these three components in the econometric part.

Substituting unobserved real output growth rates by observed nominal output growth rates, Harrison et al. (2008) derive the following equation which describes the relationship between employment growth, efficiency gains through process innovation and the sales growth due to old and new products:

$$
l=\alpha_{0}+\alpha_{1} p c+\left(g_{1}-\pi_{1}\right)+\beta g_{2}+v
$$

$g_{1}$ and $g_{2}$ denote nominal output growth (sales growth) due to old and new products, respectively, with $g_{1}=y_{1}+\pi_{1}$ and $g_{2}=y_{2}+\pi_{2} y_{2}$. The variable $g_{2}$ can be calculated using CIS data by multiplying the share of sales in $t=2$ due to new products introduced between $t=2$ and $t=1$ with the ratio of sales in $t=2$ and $t=1$. This variable is denoted SGRPD in the empirical analysis. $g_{1}$ can be calculated by the total sales growth rate $g$ minus the sales growth rate due to new products $g_{2} . \pi_{1}$ measures the price growth rate of old products at the firm level. Since firm-level prices are not available in CIS data, $\pi_{1}$ is proxied by $\tilde{\pi}_{1}$, the price growth rate of old products at the industry level (see section 4). $\pi_{2}$ denotes the price difference between the new product in $t=2$ and the old product in $t=1$ in relation to the price of the old product at the firm level. Since the coefficient of the output growth due to old products is equal to one in the theoretical model, it can be subtracted from the dependent variable $l$, so that we get the following estimation equation:

$$
l-\left(g_{1}-\tilde{\pi}_{1}\right)=\alpha_{0}+\alpha_{1} p c+\beta g_{2}+v
$$

In our study, all growth rates relate to the period 2002-2004. Many product innovations come along with a change in the production technology. In the model $p c$, however, relates to old products. We define therefore $p c$ to be one for firms which have solely introduced process innovations in the period 2002-2004 since these must refer to existing products (PC). 
Descriptive statistics are given in Table 2. One problem that arises in this model is the fact that the sales growth rate from new products $g_{2}$ is correlated with the error term $v$ since $v=-E\left(\pi_{1}-\tilde{\pi}_{1}\right)-\beta \pi_{2} y_{2}+u$. An appropriate econometric method to deal with such an endogeneity problem is to use instrumental variable techniques. The instruments should be correlated with the sales growth due to new products (i.e. innovation success), but not correlated with the error term (in particular they have to be uncorrelated with the relative price difference of new to old products). We use three dummy variables as instruments that have been found to be important in explaining innovation success: a dummy variable that indicates whether the firm does R\&D continuously (RDCONT); a variable that indicates whether the product innovation was aimed at increasing the product range (RANGE; measured on a 4 point scale), and a dummy variable that equals 1 if clients have been a high-to-medium important information source for innovation (CLIENT). These instruments are similar to the ones proposed by Harrison et al. (2008). We have tested and proved their non-weakness and validity by checking the F-statistic from the first stage regression, the Kleibergen-Paap tests on weak instruments and underidentification, the Sargan-Hansen J-Test on overidentifying restrictions for overall instrument validity and the difference-in-Sargan C-Test on the instrument validity of single instruments. ${ }^{7}$ For all regressions we employ weighted IV estimation techniques.

\section{ECONOMETRIC RESULTS}

The econometric analysis proceeds in four steps. First, we separately estimate equation (2) for manufacturing and services, but with all firms regardless of their ownership status. ${ }^{8}$ This approach assumes that the effect of innovation on employment is the same for all firms. In a second step, we relax the assumption that the effect of innovation on employment is the same for all firms and examine the linkage between innovation and employment by running separate regressions for each type of ownership. In subsection 7.3 we use the regression results of the second step to decompose the average employment growth into the contribution of general productivity trends, process innovation, output growth of existing products, and the net effect of product innovation. Finally, we check robustness of our results in subsection 7.4.

7 The tests are explained in more detail in the notes of Table 3.

8 Instead of using $l-\left(g_{1}-\tilde{\pi}_{1}\right)$ as dependent variable, we could have used $l$ as dependent variable and $\left(g_{1}-\tilde{\pi}_{1}\right)$ as additional explanatory variable where we restrict the coefficient to be 1 and would have got the same results. Therefore, we can still interpret the results in terms of employment growth. 


\subsection{Employment growth in foreign-owned and domestically owned firms}

We build on equation (2) and additionally allow the efficiency parameter $\alpha_{0}$ to vary across countries, industries, size classes and ownership types by including corresponding dummy variables. Size is measured as number of employees at the beginning of the observed period in 2002. We distinguish three sizes classes: 10-49 (SMALL), 50-249 (MEDIUM) and more than 249 employees (LARGE). ${ }^{9}$ The results for manufacturing and services are given in Table 3.

The econometric results reveal that successful product innovations are significantly related to employment growth. A higher sales growth rate due to product innovation (SGRPD) is associated with a higher employment growth rate. From the coefficient we can infer that an increase in sales growth due to new products of $1 \%$ leads to an increase in gross employment by $1 \%$ in manufacturing. The corresponding coefficient in services is significantly smaller than 1 which implies that new products are produced with a higher efficiency (less labour) than old products. At the same time, one must take into account that product innovation can displace existing products to a considerable extent which is captured by $g_{1}$. Estimation results for the net employment effect of product innovation will be discussed below.

Process innovations (PC) are associated with significant employment reductions in manufacturing. The negative though somewhat smaller coefficient of PC in services also indicates productivity gains and thus displacement of labour due to process innovation. However, this effect is not significant at conventional levels. However, this result might also partly be driven by the fact that process innovation in services is more difficult to identify than in manufacturing. Services are often customised to specific demands so that a clearly structured production process is lacking in many cases.

9 Note that the estimation equation is specified in growth rates, i.e. in first differences. This implies that timeinvariant firm-specific (observable and unobservable) effects in the employment levels are already eliminated. However, the inclusion of industry, country and ownership dummies enlarge the flexibility of the specification by allowing for an unspecified form of heterogeneity in the growth rates between industries, countries and ownership types. 
Table 3: Effect of foreign ownership on employment growth, 2002-2004

\begin{tabular}{|c|c|c|c|c|c|c|c|c|}
\hline & \multicolumn{4}{|c|}{ Manufacturing } & \multicolumn{4}{|c|}{ Services } \\
\hline & (1) & (2) & (3) & (4) & (1) & (2) & (3) & (4) \\
\hline Const. & $\begin{array}{l}-14.878^{* * *} \\
(1.482)\end{array}$ & $\begin{array}{l}-14.062 * * * \\
(1.501)\end{array}$ & $\begin{array}{l}-14.020^{* * *} \\
(1.501)\end{array}$ & $\begin{array}{l}-14.015^{* * *} \\
(1.501)\end{array}$ & $\begin{array}{l}-11.144 * * * \\
(2.083) \\
\end{array}$ & $\begin{array}{l}-10.338^{* * *} \\
(2.073) \\
\end{array}$ & $\begin{array}{l}-10.348 * * * \\
(2.077)\end{array}$ & $\begin{array}{l}-10.375^{* * *} \\
(2.076)\end{array}$ \\
\hline Innovation & & & & & & & & \\
\hline SGRPD & $\begin{array}{l}0.998 * * * \\
(0.021)\end{array}$ & $\begin{array}{l}1.011 * * * \\
(0.021)\end{array}$ & $\begin{array}{l}1.011^{* * *} \\
(0.021)\end{array}$ & $\begin{array}{l}1.011^{* * *} \\
(0.021)\end{array}$ & $\begin{array}{l}0.893 * * * \\
(0.038)\end{array}$ & $\begin{array}{l}0.903 * * * \\
(0.038)\end{array}$ & $\begin{array}{l}0.903 * * * \\
(0.038)\end{array}$ & $\begin{array}{l}0.903 * * * \\
(0.038)\end{array}$ \\
\hline PC & $\begin{array}{c}-2.171^{* *} \\
(0.852)\end{array}$ & $\begin{array}{c}-1.970^{* *} \\
(0.851)\end{array}$ & $\begin{array}{c}-1.970^{* *} \\
(0.851)\end{array}$ & $\begin{array}{c}-1.973^{* *} \\
(0.851)\end{array}$ & $\begin{array}{l}-1.5730 \\
(1.228)\end{array}$ & $\begin{array}{l}-1.598 \\
(1.228)\end{array}$ & $\begin{array}{l}-1.599 \\
(1.228)\end{array}$ & $\begin{array}{l}-1.603 \\
(1.228)\end{array}$ \\
\hline Ownership & & & & & & & & \\
\hline DGF & $\begin{array}{l}-3.407 * * * \\
(0.761)\end{array}$ & $\begin{array}{l}-2.640^{* * *} \\
(0.813)\end{array}$ & $\begin{array}{l}-2.632 * * * \\
(0.813)\end{array}$ & $\begin{array}{l}-2.623^{* * *} \\
(0.812)\end{array}$ & $\begin{array}{l}-2.396 * * \\
(1.123)\end{array}$ & $\begin{array}{l}-1.670 \\
(1.155)\end{array}$ & $\begin{array}{l}-1.671 \\
(1.156)\end{array}$ & $\begin{array}{l}-1.689 \\
(1.154)\end{array}$ \\
\hline FOF & $\begin{array}{l}-3.377^{* * *} \\
(0.674)\end{array}$ & $\begin{array}{l}-2.204^{* * *} \\
(0.737)\end{array}$ & - & - & $\begin{array}{l}-5.576^{* * *} \\
(1.554)\end{array}$ & $\begin{array}{l}-4.862^{* * *} \\
(1.613)\end{array}$ & - & - \\
\hline FOFEU & - & - & $\begin{array}{c}-2.529 * * * \\
(0.822)\end{array}$ & $\begin{array}{c}-2.518 * * * \\
(0.821)\end{array}$ & - & - & $\begin{array}{c}-4.786 * * \\
(1.882)\end{array}$ & $\begin{array}{c}-4.804^{* *} \\
(1.882)\end{array}$ \\
\hline FOFNONEU & - & - & $\begin{array}{l}-1.417 \\
(1.054)\end{array}$ & - & - & - & $\begin{array}{c}-5.039 * \\
(2.625)\end{array}$ & - \\
\hline FOFUS & - & - & - & $\begin{array}{l}-0.932 \\
(1.265)\end{array}$ & - & - & - & $\begin{array}{c}-7.596 * \\
(3.979)\end{array}$ \\
\hline FOFROW & - & - & - & $\begin{array}{c}-2.023 \\
(1.612)\end{array}$ & - & - & - & $\begin{array}{l}-2.449 \\
(3.040)\end{array}$ \\
\hline $\begin{array}{l}\text { Country } \\
\text { dummies }\end{array}$ & & & & & & & & \\
\hline BG & $\begin{array}{l}1.711 \\
(1.311)\end{array}$ & $\begin{array}{l}1.507 \\
(1.313)\end{array}$ & $\begin{array}{l}1.4712 \\
(1.313)\end{array}$ & $\begin{array}{l}1.474 \\
(1.313)\end{array}$ & $\begin{array}{l}1.436 \\
(2.196)\end{array}$ & $\begin{array}{l}0.797 \\
(2.195)\end{array}$ & $\begin{array}{l}0.806 \\
(2.197)\end{array}$ & $\begin{array}{l}0.835 \\
(2.197)\end{array}$ \\
\hline $\mathrm{CZ}$ & $\begin{array}{l}9.074 * * * \\
(1.310)\end{array}$ & $\begin{array}{l}8.816^{* * *} \\
(1.312)\end{array}$ & $\begin{array}{l}8.798^{* * *} \\
(1.312)\end{array}$ & $\begin{array}{l}8.801 * * * \\
(1.312)\end{array}$ & $\begin{array}{l}9.813 * * * \\
(2.192)\end{array}$ & $\begin{array}{l}9.198 * * * \\
(2.193)\end{array}$ & $\begin{array}{l}9.204 * * * \\
(2.194)\end{array}$ & $\begin{array}{l}9.237 * * * \\
(2.194)\end{array}$ \\
\hline DK & $\begin{array}{l}26.973^{* * *} \\
(1.803)\end{array}$ & $\begin{array}{l}26.381^{* * *} \\
(1.804)\end{array}$ & $\begin{array}{l}26.332^{* * *} \\
(1.806)\end{array}$ & $\begin{array}{l}26.325^{* * *} \\
(1.806)\end{array}$ & $\begin{array}{l}20.675^{* * *} \\
(2.368)\end{array}$ & $\begin{array}{l}20.028^{* * *} \\
(2.363)\end{array}$ & $\begin{array}{l}20.043^{* * *} \\
(2.372)\end{array}$ & $\begin{array}{l}20.010^{* * *} \\
(2.369)\end{array}$ \\
\hline $\mathrm{EE}$ & $\begin{array}{l}3.846^{* *} \\
(1.780)\end{array}$ & $\begin{array}{l}3.372 * \\
(1.788)\end{array}$ & $\begin{array}{l}3.356^{*} \\
(1.788)\end{array}$ & $\begin{array}{l}3.358^{*} \\
(1.788)\end{array}$ & $\begin{array}{l}3.399 \\
(2.856)\end{array}$ & $\begin{array}{l}2.618 \\
(2.865)\end{array}$ & $\begin{array}{l}2.622 \\
(2.865)\end{array}$ & $\begin{array}{l}2.665 \\
(2.864)\end{array}$ \\
\hline ES & $\begin{array}{l}9.066^{* * * *} \\
(1.259)\end{array}$ & $\begin{array}{l}8.418^{* * * *} \\
(1.264)\end{array}$ & $\begin{array}{l}8.379 * * * \\
(1.264)\end{array}$ & $\begin{array}{l}8.378^{* * *} \\
(1.264)\end{array}$ & $\begin{array}{l}9.982 * * * \\
(2.289)\end{array}$ & $\begin{array}{l}9.280^{* * * *} \\
(2.272)\end{array}$ & $\begin{array}{l}9.290 * * * \\
(2.279)\end{array}$ & $\begin{array}{l}9.329 * * * \\
(2.278)\end{array}$ \\
\hline FR & $\begin{array}{l}13.023^{* * *} \\
(1.472)\end{array}$ & $\begin{array}{l}12.403^{* * *} \\
(1.472)\end{array}$ & $\begin{array}{l}12.356^{* * *} \\
(1.474)\end{array}$ & $\begin{array}{l}12.349 * * * \\
(1.473)\end{array}$ & $\begin{array}{l}12.207 * * * \\
(2.214)\end{array}$ & $\begin{array}{l}11.482^{* * *} \\
(2.190)\end{array}$ & $\begin{array}{l}11.494^{* * *} \\
(2.193)\end{array}$ & $\begin{array}{l}11.536^{* * *} \\
(2.191)\end{array}$ \\
\hline GR & $\begin{array}{l}12.410^{* * * *} \\
(2.426)\end{array}$ & $\begin{array}{l}11.702 * * * \\
(2.437)\end{array}$ & $\begin{array}{l}11.654^{* * * *} \\
(2.439)\end{array}$ & $\begin{array}{l}11.644^{* * *} \\
(2.439)\end{array}$ & $\begin{array}{l}12.743^{* * *} \\
(3.0139)\end{array}$ & $\begin{array}{l}12.043^{* * * *} \\
(3.022)\end{array}$ & $\begin{array}{l}12.053^{* * * *} \\
(3.020)\end{array}$ & $\begin{array}{l}12.068^{* * *} \\
(3.023)\end{array}$ \\
\hline $\mathrm{HU}$ & $\begin{array}{l}14.675^{* * *} \\
(1.442)\end{array}$ & $\begin{array}{l}14.359 * * * \\
(1.442)\end{array}$ & $\begin{array}{l}14.330^{* * *} \\
(1.442)\end{array}$ & $\begin{array}{l}14.332^{* * *} \\
(1.442)\end{array}$ & $\begin{array}{l}10.656^{* * * *} \\
(2.507)\end{array}$ & $\begin{array}{l}10.037^{* * *} \\
(2.505)\end{array}$ & $\begin{array}{l}10.044 * * * \\
(2.506)\end{array}$ & $\begin{array}{l}10.098 * * * \\
(2.506)\end{array}$ \\
\hline IT & $\begin{array}{l}19.672^{* * *} \\
(1.249)\end{array}$ & $\begin{array}{l}18.998^{* * * *} \\
(1.251)\end{array}$ & $\begin{array}{l}18.955^{* * *} \\
(1.251)\end{array}$ & $\begin{array}{l}18.954^{* * *} \\
(1.252)\end{array}$ & $\begin{array}{l}18.929 * * * \\
(2.167)\end{array}$ & $\begin{array}{l}18.171^{* * *} \\
(2.153)\end{array}$ & $\begin{array}{l}18.183^{* * *} \\
(2.161)\end{array}$ & $\begin{array}{l}18.202^{* * *} \\
(2.160)\end{array}$ \\
\hline LU & $\begin{array}{l}16.547 * * * \\
(2.141)\end{array}$ & $\begin{array}{l}16.193^{* * *} \\
(2.145)\end{array}$ & $\begin{array}{l}16.166^{* * * *} \\
(2.146)\end{array}$ & $\begin{array}{l}16.146^{* * *} \\
(2.146)\end{array}$ & $\begin{array}{l}23.124^{* * *} \\
(2.883)\end{array}$ & $\begin{array}{l}22.338 * * * \\
(2.894)\end{array}$ & $\begin{array}{l}22.342 * * * \\
(2.893)\end{array}$ & $\begin{array}{l}22.372 * * * \\
(2.895)\end{array}$ \\
\hline LV & $\begin{array}{l}-0.969 \\
(2.219)\end{array}$ & $\begin{array}{l}-1.235 \\
(2.218)\end{array}$ & $\begin{array}{l}-1.270 \\
(2.218)\end{array}$ & $\begin{array}{l}-1.267 \\
(2.219)\end{array}$ & $\begin{array}{l}9.642 * * \\
(4.046)\end{array}$ & $\begin{array}{l}9.016^{* *} \\
(4.041)\end{array}$ & $\begin{array}{l}9.021^{* *} \\
(4.041)\end{array}$ & $\begin{array}{l}9.079 * * \\
(4.042)\end{array}$ \\
\hline NO & $\begin{array}{l}21.687 * * * \\
(1.410)\end{array}$ & $\begin{array}{l}21.025^{* * * *} \\
(1.425)\end{array}$ & $\begin{array}{l}20.994^{* * * *} \\
(1.425)\end{array}$ & $\begin{array}{l}20.989 * * * \\
(1.425)\end{array}$ & $\begin{array}{l}19.627^{* * *} \\
(2.322)\end{array}$ & $\begin{array}{l}18.799 * * * \\
(2.331)\end{array}$ & $\begin{array}{l}18.806^{* * * *} \\
(2.333)\end{array}$ & $\begin{array}{l}18.873^{* * *} \\
(2.333)\end{array}$ \\
\hline PT & $\begin{array}{l}11.496^{* * *} \\
(1.375)\end{array}$ & $\begin{array}{l}11.006^{* * *} \\
(1.381)\end{array}$ & $\begin{array}{l}10.965^{* * * *} \\
(1.382)\end{array}$ & $\begin{array}{l}10.967 * * * \\
(1.382)\end{array}$ & $\begin{array}{l}12.106 * * * \\
(2.458)\end{array}$ & $\begin{array}{l}11.380^{* * * *} \\
(2.452)\end{array}$ & $\begin{array}{l}11.389 * * * \\
(2.453)\end{array}$ & $\begin{array}{l}11.403^{* * * *} \\
(2.452)\end{array}$ \\
\hline RO & $\begin{array}{l}43.897 * * * \\
(1.596)\end{array}$ & $\begin{array}{l}43.839 * * * \\
(1.594)\end{array}$ & $\begin{array}{l}43.793^{* * * *} \\
(1.594)\end{array}$ & $\begin{array}{l}43.799 * * * \\
(1.594)\end{array}$ & $\begin{array}{l}47.263^{* * *} \\
(2.301)\end{array}$ & $\begin{array}{l}46.790 * * * \\
(2.293)\end{array}$ & $\begin{array}{l}46.799 * * * \\
(2.295)\end{array}$ & $\begin{array}{l}46.816 * * * \\
(2.295)\end{array}$ \\
\hline SI & $\begin{array}{l}4.587^{* *} \\
(2.033) \\
\end{array}$ & $\begin{array}{l}4.481^{* *} \\
(2.038) \\
\end{array}$ & $\begin{array}{l}4.459 * * \\
(2.037) \\
\end{array}$ & $\begin{array}{l}4.463 * * \\
(2.037) \\
\end{array}$ & $\begin{array}{l}6.998 * * \\
(3.359) \\
\end{array}$ & $\begin{array}{l}6.263^{*} \\
(3.359) \\
\end{array}$ & $\begin{array}{l}6.276^{*} \\
(3.362) \\
\end{array}$ & $\begin{array}{l}6.234^{*} \\
(3.357) \\
\end{array}$ \\
\hline Size dut & & & & & & & & \\
\hline MEDIUM & - & $\begin{array}{l}-2.543^{* * *} \\
(0.482)\end{array}$ & $\begin{array}{l}-2.547 * * * \\
(0.482)\end{array}$ & $\begin{array}{l}-2.554 * * * \\
(0.482)\end{array}$ & - & $\begin{array}{l}-2.835^{* * *} \\
(0.787)\end{array}$ & $\begin{array}{l}-2.834 * * * \\
(0.787)\end{array}$ & $\begin{array}{l}-2.802 * * * \\
(0.787)\end{array}$ \\
\hline LARGE & - & $\begin{array}{l}-2.221 * * * \\
(0.586)\end{array}$ & $\begin{array}{l}-2.254 * * * \\
(0.586)\end{array}$ & $\begin{array}{l}-2.280 * * * \\
(0.584)\end{array}$ & - & $\begin{array}{l}-5.313^{* * *} \\
(0.936)\end{array}$ & $\begin{array}{l}-5.313^{* * * *} \\
(0.935)\end{array}$ & $\begin{array}{l}-5.268 * * * \\
(0.938)\end{array}$ \\
\hline Industry dum. & $0.000^{* * *}$ & $0.000 * * *$ & $0.000 * * *$ & $0.000 * * *$ & $0.000 * * *$ & $0.000 * * *$ & $0.000 * * *$ & $0.000 * * *$ \\
\hline
\end{tabular}


Table 3: Effect of foreign ownership on employment growth, 2002-2004 (cont')

\begin{tabular}{l|llll|llll}
\hline R2adj & 0.4159 & 0.4153 & 0.4153 & 0.4152 & 0.3456 & 0.3463 & 0.3463 & 0.3464 \\
\hline H0: $=1$ & 0.9086 & 0.6062 & 0.6083 & 0.6098 & $0.0049^{* * *}$ & $0.0110^{* *}$ & $0.0110^{* *}$ & $0.0107^{* *}$ \\
\hline $\begin{array}{l}\text { H0: SGRPD } \\
\text { exogenous }\end{array}$ & $0.0000^{* * *}$ & $0.0000^{* * *}$ & $0.0000^{* * *}$ & $0.0000^{* * *}$ & 0.5228 & 0.3524 & 0.3522 & 0.3590 \\
J-Test & & & & & & & & \\
C: RANGE & 0.6099 & 0.3670 & 0.3685 & 0.3737 & 0.7794 & 0.7213 & 0.7214 & 0.7330 \\
C:CLIENT & 0.5534 & 0.3871 & 0.3873 & 0.3886 & 0.6666 & 0.6133 & 0.6148 & 0.6134 \\
C: R\&D & 0.8879 & 0.1601 & 0.1610 & 0.1641 & 0.4819 & 0.4214 & 0.4217 & 0.4350 \\
\hline First stage & & 0.8761 & 0.8776 & 0.8819 & 0.9292 & 0.9309 & 0.9305 & 0.9467 \\
statistics: & & & & & & & & \\
RANGE & $8.012^{* * *}$ & $8.045^{* * *}$ & $8.046^{* * *}$ & $8.044^{* * *}$ & $8.755^{* * *}$ & $8.784^{* * *}$ & $8.787 * * *$ & $8.787^{* * *}$ \\
& $(0.339)$ & $(0.340)$ & $(0.340)$ & $(0.340)$ & $(0.517)$ & $(0.518)$ & $(0.518)$ & $(0.518)$ \\
RDCONT & $7.088^{* * *}$ & $7.456^{* * *}$ & $7.456^{* * *}$ & $7.465^{* * *}$ & $11.529^{* * *}$ & $11.683^{* * *}$ & $11.687 * * *$ & $11.691^{* * *}$ \\
& $(1.107)$ & $(1.037)$ & $(1.037)$ & $(1.037)$ & $(1.645)$ & $(1.655)$ & $(1.655)$ & $(1.657)$ \\
CLIENT & $7.445^{* * *}$ & $7.525^{* * *}$ & $7.525^{* * *}$ & $7.522^{* * *}$ & $7.160^{* * *}$ & $7.196^{* * *}$ & $7.184^{* * *}$ & $7.183^{* * *}$ \\
& $(0.852)$ & $(0.854)$ & $(0.854)$ & $(0.854)$ & $(1.221)$ & $(1.221)$ & $(1.221)$ & $(1.221)$ \\
\hline F overall & $114.59^{* * *}$ & $137.97^{* * *}$ & $133.91^{* * *}$ & $130.10^{* * *}$ & $62.09^{* * *}$ & $69.89^{* * *}$ & $67.58^{* * *}$ & $65.85^{* * *}$ \\
Partial R2 & 0.2556 & 0.2531 & 0.2531 & 0.2531 & 0.2683 & 0.2670 & 0.2686 & 0.2685 \\
H0: underident. & $1077.5^{* * *}$ & $976.14^{* * *}$ & $976.03^{* * *}$ & $976.48^{* * *}$ & $511.62^{* * *}$ & $492.96^{* * *}$ & $493.10^{* * *}$ & $492.47^{* * *}$ \\
H0: Weak instr. & $536.21^{* * *}$ & $485.37^{* * *}$ & $485.25^{* * *}$ & $485.40^{* * *}$ & $252.29^{* * *}$ & $244.90^{* * *}$ & $245.07^{* * *}$ & $244.77^{* * *}$ \\
\hline Obs & 40920 & 40920 & 40920 & 40920 & 23726 & 23726 & 23726 & 23726 \\
\hline
\end{tabular}

Notes: Method: weighted instrumental variables estimation. Estimates are based on pooled data. Reference country: Slovakia (SK). Heteroskedasticity-robust standard errors are in parentheses. $* * *, * *$ and $*$ indicates significance at the $1 \%, 5 \%$ and $10 \%$ level. Industry dummies are included in each regression. Reported is the p-value of a test on joint significance of the industry dummies. Instruments for sales growth due to new products (SGRPD): RANGE (product innovation was aimed to increasing product range: measured on a 4-point Likert scale (4: high importance; 0 not important), RDCONT (dummy for continuous R\&D activity) and CLIENT (dummy equals 1 if clients have been a high-to-medium-sized information source of innovation). J-Test reports the p-value of the Sargan-Hansen test on overidentifying restrictions. Under H0 (overall set of instruments is valid) $\mathrm{J}$ follows a $X^{2}(m)$ distribution with $\mathrm{m}$ as the number of overidentifying restrictions. The difference-inSargan C-Test reports the p-value of a difference-in-Sargan test on the validity of a single instrument. "HO: SGRPD exogenous" tests on the exogeneity of sales growth due to new products using a difference-in-Sargan test statistic. The test statistic is robust to violations of conditional homoskedasticity. If conditional homoskedasticity holds, it is numerically equal to a Hausman-Durbin-Wu test statistic. First stage statistics: Reported are only coefficients and standard errors of the instruments, results for the other exogenous variables in the first stage are available upon request. F overall reports the test statistic of an F-Test on the joint significance of all variables (exogenous and instruments) in the first stage. Partial R2 measures the explanatory power of the instruments (it is the R2 of the first stage regression where other explanatory variables have been partialled out). "HO: underident." is a test on whether the equation is identified, i.e., that the excluded instruments are relevant meaning correlated with the endogenous regressors. Reported is the heteroskedasticity-robust Kleibergen-Paap rk LM statistic (Kleibergen and Paap, 2006) which follows here a $X^{2}(3)$-distribution. Weak instruments can lead to a large relative bias of IV compared to the bias of OLS. "HO: weak instr." tests the null hypothesis that the instruments are weak, more precisely that the maximal relative bias of IV is larger 5\%. Reported is the heteroskedasticity-robust Kleibergen-Paap rk Wald F statistic. The critical value is 13.91 (critical value is for the Cragg-Donald F statistic and i.i.d. errors; see Baum et al., 2007; Cragg and Donald, 1993; Stock and Yogo, 2005).

Source: CIS 4, Eurostat, own calculation.

Estimation results furthermore indicate a significantly smaller employment growth rate for FOF compared to DnGF. This holds even when we control for initial firm size. In manufacturing, the employment growth rate is also significantly smaller for DGF than for DnGF. This is in line with the descriptive results of Figure 2. FOF in services, in contrast, exhibit significant lower growth rates compared to DGF and DnGF. FOF in manufacturing, but not in services, behave very much like DGF. Moreover, econometric results reveal that DGF create less employment growth than DnGF in manufacturing, but not in service industries. 
Employment growth of FOF also depends on the home country of the parent company. In manufacturing, European FOF grew more slowly than FOF having a parent company in the US or in the rest of the world. In services, FOF from the US create significantly less employment than domestic firms but also than European FOF or FOF from the rest of the world. Comparing the latter two subgroups, employment growth of European FOF turns out to be lower.

Unfortunately, a few large EU countries such as Germany and the UK have not provided their CIS4 micro data to Eurostat. One may wonder how this impacts our results. Harrison et al. (2008) found very similar results concerning the impact of product and process innovation on employment growth in Germany and the UK for the period 1998-2000, though they did not account for ownership in their regressions.

\subsection{Innovation-induced employment growth by ownership type}

The previous subsection has shown that employment growth varies significantly with ownership type. We now relax the assumption that the effect of innovation on employment is the same for all firms and ask whether and how the observed differences in employment creation between foreign-owned and domestically owned firms are related to differences in process and product innovation. We examine this question by running separate regressions for each type of ownership (see Table 4 and 5 for manufacturing and services, respectively). The goodness of fit of the model, measured by the adjusted R2, is quite high for microeconometric analyses, ranging from 0.4 to 0.55 in manufacturing and 0.33 to 0.41 in services.

The results corroborate a positive impact of sales growth due to new products (SGRPD) on gross employment (compensation effect) for DnGF, DGF and FOF. In the model, the coefficient measures the productivity effect of new products. A value of less than one indicates that new products are produced more efficiently than old ones. Results show a decline in the parameter estimates from DnGF over DGF to FOF. A corresponding one-sided t-test confirms that in manufacturing the coefficient is significantly smaller than 1 for FOF at least from NON-EU countries (p-value: 0.035) but not for DnGF and DGF. Thus, parts of FOF were able to produce their new products with a significantly higher efficiency than domestically owned firms, implying less employment growth and confirming H1b. Note that the period 2002-2004 was characterized by a recession in many countries. Another reason for this result could be that globally active multinational firms are exposed to a higher cost pressure in recession periods so that they target efficient production of new products more heavily. 
Table 4: Effect of innovation on employment growth by ownership, manufacturing

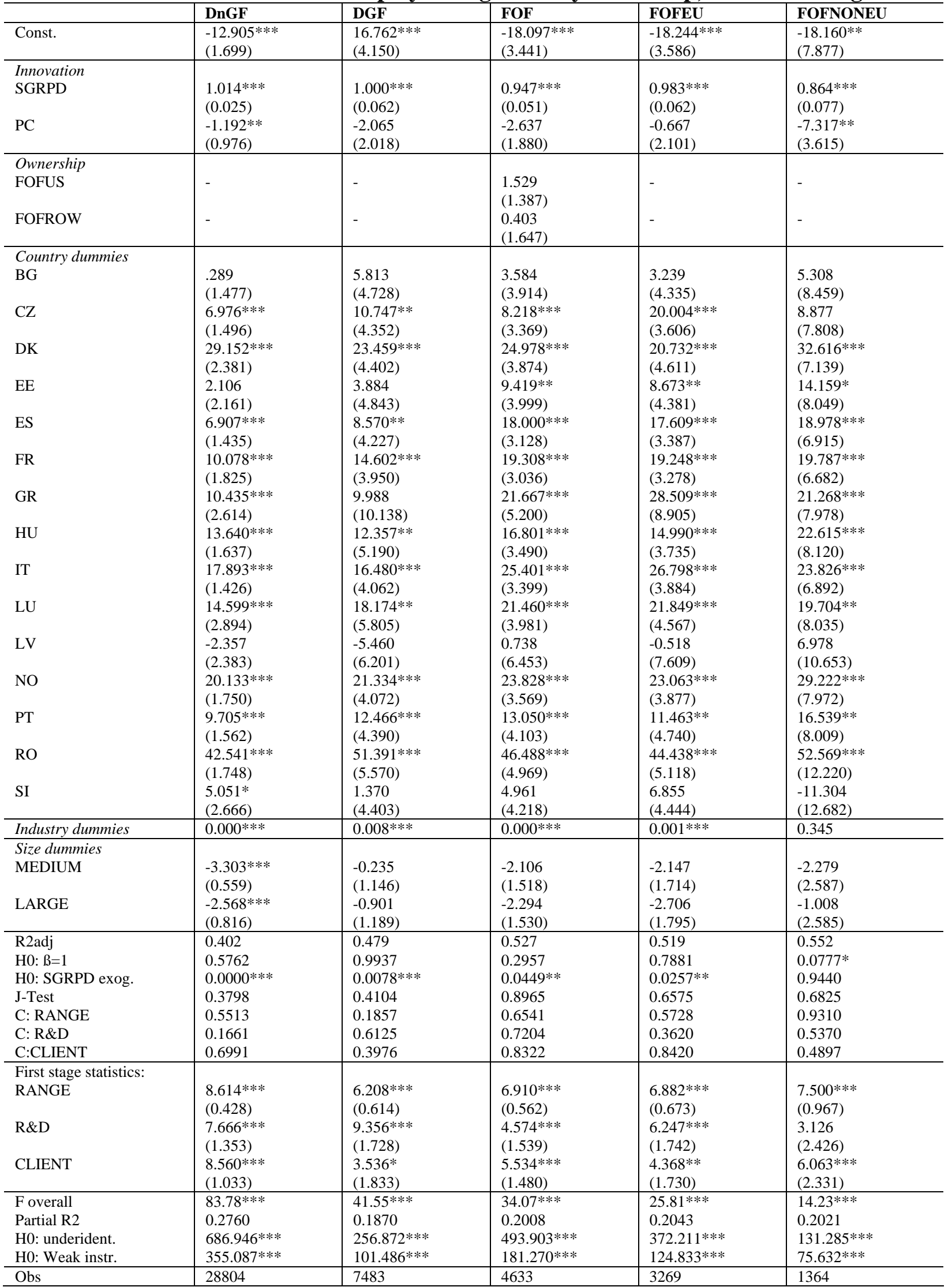

Notes: Method: weighted instrumental variables estimation. For further explanations see Table 3. For FOFNONEU the hypothesis that SGRPD is exogenous cannot be rejected. Instead of IV we also run OLS and find very similar results. For instance, for SGRPD: 0.852*** (0.033) and PC: -7.531** (3.095).

Source: CIS 4, Eurostat, own calculation. 
Table 5: Effect of innovation on employment growth by ownership, services

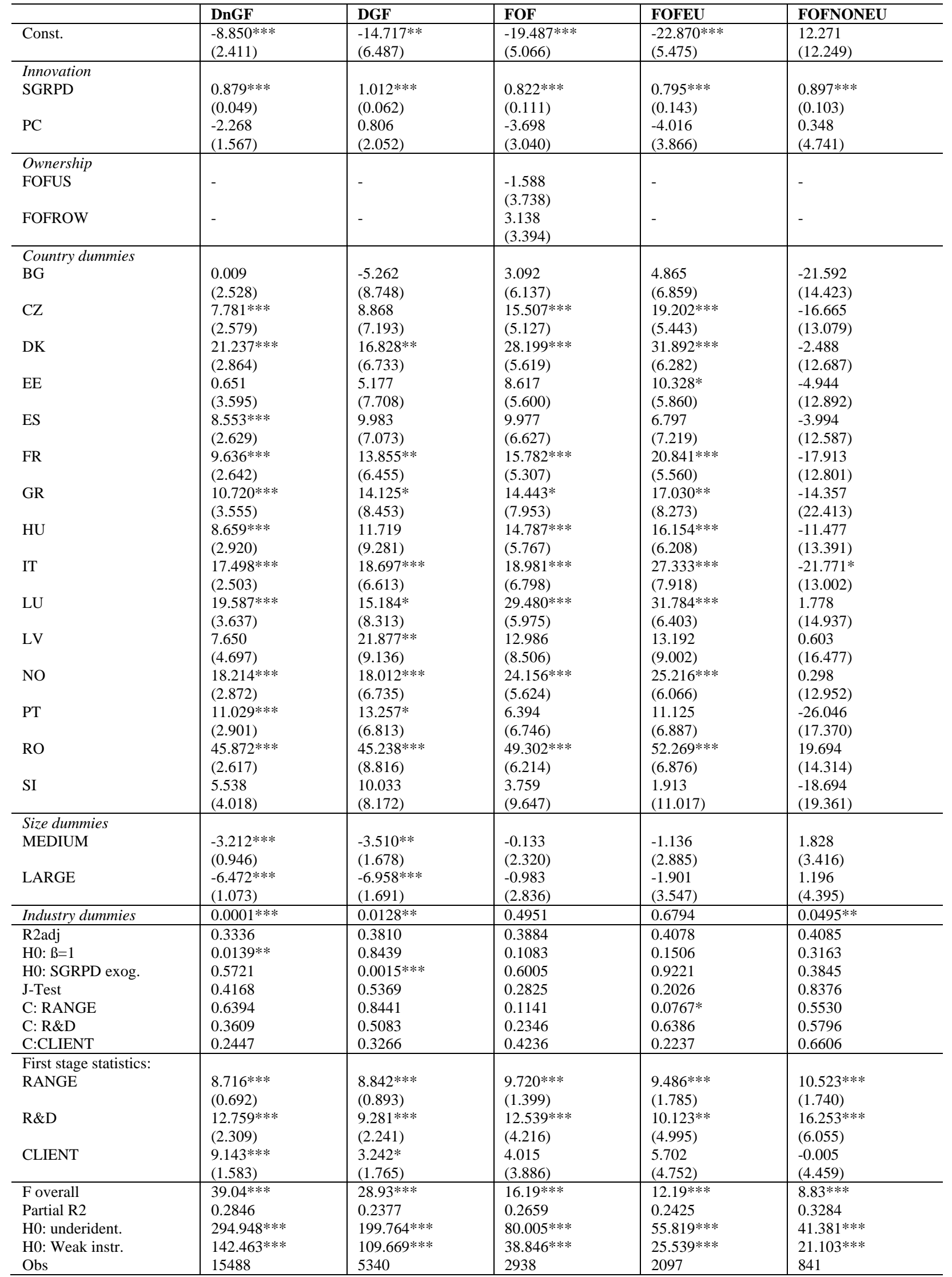

Notes: Method: weighted instrumental variables estimation. For further explanations see Table 3.

Source: CIS 4, Eurostat, own calculation. 
In services, we can only partly confirm H1b. The coefficient is likewise significantly smaller than 1 (p-value: 0.054) in FOF, but not for DGF, implying that the productivity (employment) effect associated with the introduction of new products is larger (smaller) for FOF than for DGF. Compared to DnGF, this productivity effect is larger for FOF, but statistically not significantly different. In contrast to manufacturing, productivity effects are especially large for FOF from EU countries.

For process innovation (PC) we find that ownership status and the home country of the parent company matters for employment. Process innovations are responsible for a significant labour reduction only in DnGF and in non-European FOF. As stated in H2a, we find the average efficiency gain of new production technologies $\left(\alpha_{1}\right)$ to be significantly larger for nonEuropean FOF than for DnGF and for DGF. However, we cannot confirm H2a for European FOF. The result of larger efficiency gains of process innovation for non-European FOF is in line with that for product innovation showing larger productivity gains between new and old products for this group of firms. The results furthermore show that the efficiency gains for European FOF in services are nearly two times larger than for domestic firms though none of the effects is statistically significant. Likewise this is in line with the findings for product innovation.

\subsection{Disentangling general productivity trends, demand effects, and the effects of process and product innovation}

The model estimates in section 7.2 do not allow us to separate the compensation effect of process innovation and the demand effect of product innovation on existing products which are both captured by $g_{1}$. In order to evaluate the contribution of process and product innovation to employment growth, Harrison et al. (2008) additionally propose an employment growth decomposition. It allows us to separate the effects of product and process innovation from effects arising from general demand and productivity trends. They suggest decomposing the average employment growth in the following way:

$$
l=\underbrace{\hat{\alpha}_{0}}_{1}+\underbrace{\hat{\alpha}_{1} p c}_{2}+\underbrace{\left[1-I\left(g_{2}>0\right)\right]\left(g_{1}-\tilde{\pi}_{1}\right)}_{3}+\underbrace{I\left(g_{2}>0\right)\left(g_{1}-\tilde{\pi}_{1}+\hat{\beta} g_{2}\right)}_{4}+\hat{v}
$$

$\mathrm{I}(\cdot)$ is a so-called indicator function. It is 1 if the condition in brackets is fulfilled and 0 otherwise. Thus, employment growth can be decomposed into four terms: 
1. The first term measures the change in employment due to general industry and country specific productivity trends in the production of old products. It is the average effect across innovators and non-innovators. Here, general means that these effects are not attributable to process or product innovation. They rather reflect the effects of organisational change, corporate restructuring, acquisitions of firms, changes in human capital endowment, training, productivity effects from spillovers etc.

2. The second term presents the productivity or displacement effect of process innovation related to the production of old products.

3. The third term captures the employment change associated with output growth of old products for firms that do not introduce new products. That is, the third component accounts for changes in employment growth due to shifting demand for the existing product. This shift in demand can be the result of price reductions, cyclical impacts, changes in consumers' preferences but also rivals' product innovations. That is, it also catches the externalities from product innovation between firms known as the 'business stealing' effect. Substitution between sales from old and from new products within the same firm, however, is included in the subsequent fourth term.

4. The fourth term summarises the net contribution of product innovation to employment growth for product innovators. This effect results from increases in the demand for the new product $\left(I\left(g_{2}>0\right) \hat{\beta} g_{2}\right)$ and possible shifts in demand for the old one $\left(I\left(g_{2}>0\right)\left(g_{1}-\tilde{\pi}_{1}\right)\right)$. In Figure 3 and 4 the net effect and its two components are shown.

The final term is the residual which is zero by definition. A dissection of the average employment growth can be obtained by inserting the estimated coefficients and the average shares of innovators and price and sales growth rates from the sample into the equation.

Figure 3 depicts the decomposition of employment growth in manufacturing by type of ownership. The general productivity trend exerts a considerable negative influence on employment in DGF and FOF. Both, DGF and FOF experience a much higher general productivity increase than DnGF which leads to a decrease in employment by roughly $4 \%$ in DGF and 5\% in FOF between 2002 and 2004. Remember that we find larger productivity gains (displacement effects) from process and product innovation for non-European FOF than for European FOF. Interestingly, it is the opposite for the general productivity trend. European FOF experienced the largest employment reductions due to non-innovation related productivity gains. For all three groups of firms (DnGF, DGF and FOF) another small 
negative effect of around 0.3 to $0.4 \%$ on employment comes from process innovation. For non-European FOF this displacement effect rises to $0.9 \%$.

Figure 3: Decomposition of employment growth by ownership, manufacturing, 20022004

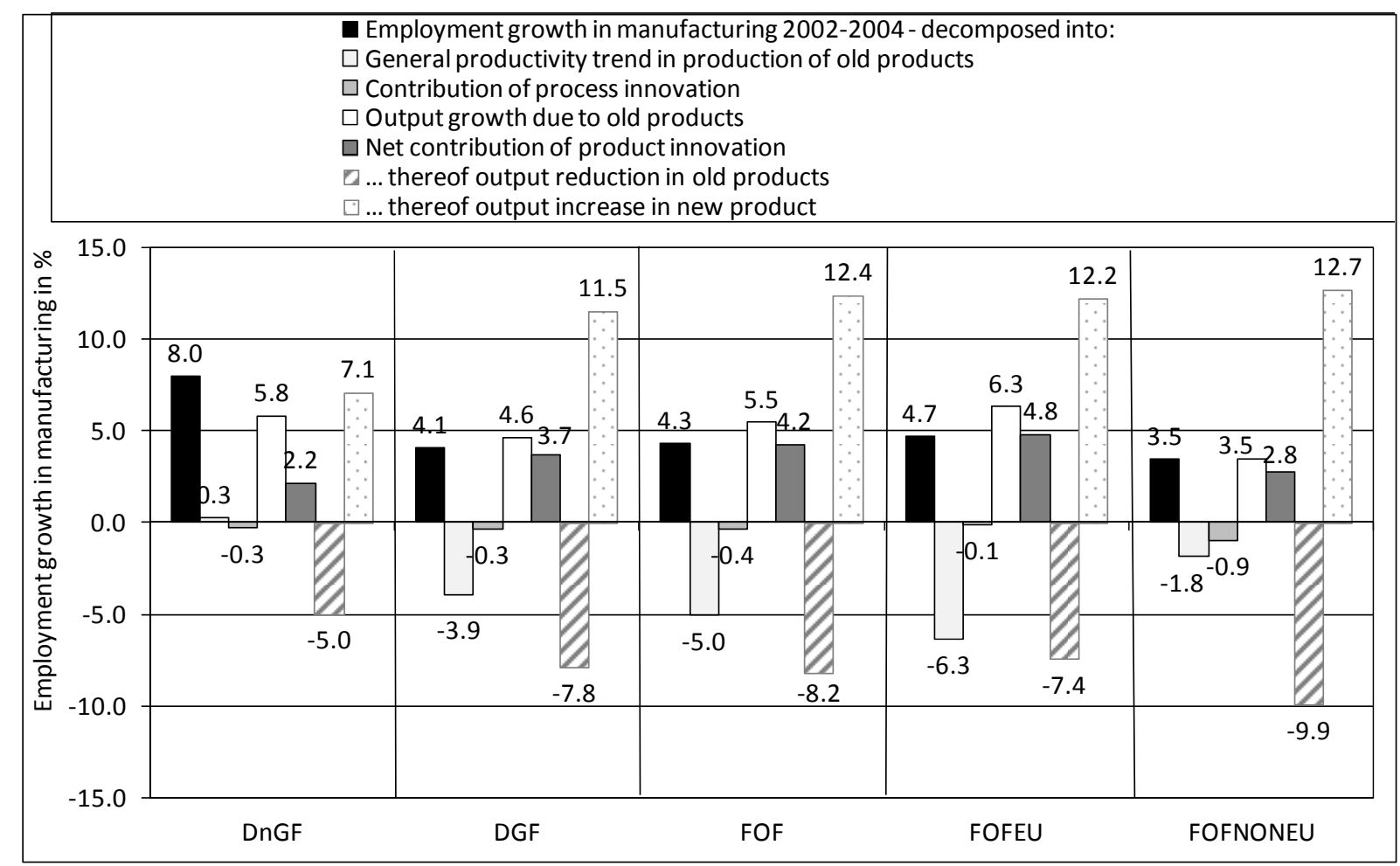

Source: CIS 4, Eurostat, own calculation.

The effects of the general productivity trend and process innovation on employment, however, are outweighed in each sub-sample by the compensation effect - the employmentcreating effects of growth in demand for old and new products. Comparing old and new products, it turns out that output growth of old products contributes more to employment growth than product innovation in all sub-samples. A similar result was found by Harrison et al. (2008) for Spain and the UK, whereas product innovation contributed more to employment in Germany and France. In absolute terms, employment creation due to the demand for old products is highest for European FOFs (6.3\%), closely followed by DnGF (5.8\%). In DGF demand growth for old products spurs employment by $4.6 \%$.

Larger differences between FOF, DnGF and DGF can be detected in the net contribution of product innovation to employment growth. In FOF-EU new products contribute more to employment growth than in DGF and DnGF. This indicates that foreign-owned firms from other European countries generate more employment growth than domestically owned firms with product innovation which supports H1. However, H1 is only partly supported for non- 
European FOF. They create more employment growth due to product innovation than DnGF, but not than DGF. We can explain this result by looking more deeply at the different components entering the fourth term. We can ascertain higher sales growth rates due to new products for both types of FOF and thus support for H1a. The econometric analysis has already revealed that new products are produced with higher efficiency (H1b). However, we find smaller sales growth rates with existing products for FOFNONEU and thus no evidence for larger indirect employment effects (either less negative or stronger positive) as postulated in $\mathrm{H} 1 \mathrm{c}$.

Figure 4 depicts the results of the decomposition of employment growth for service industries. The general pattern is the same as for manufacturing: We observe strong employment losses due to general productivity increases in FOF and DGF. In contrast, unaffiliated firms have still unexploited efficiency gains which can be inferred from the positive general productivity effect. Like in manufacturing, process innovation contributes only little to employment changes in services. Employment grows in all sub-samples of firms because employment losses induced by general productivity increases and process innovation are overcompensated by the effects stemming from output growth for old products and by the contribution of product innovation. This result is the same for all types of ownership.

Figure 4: Decomposition of employment growth by ownership, services, 2002-2004

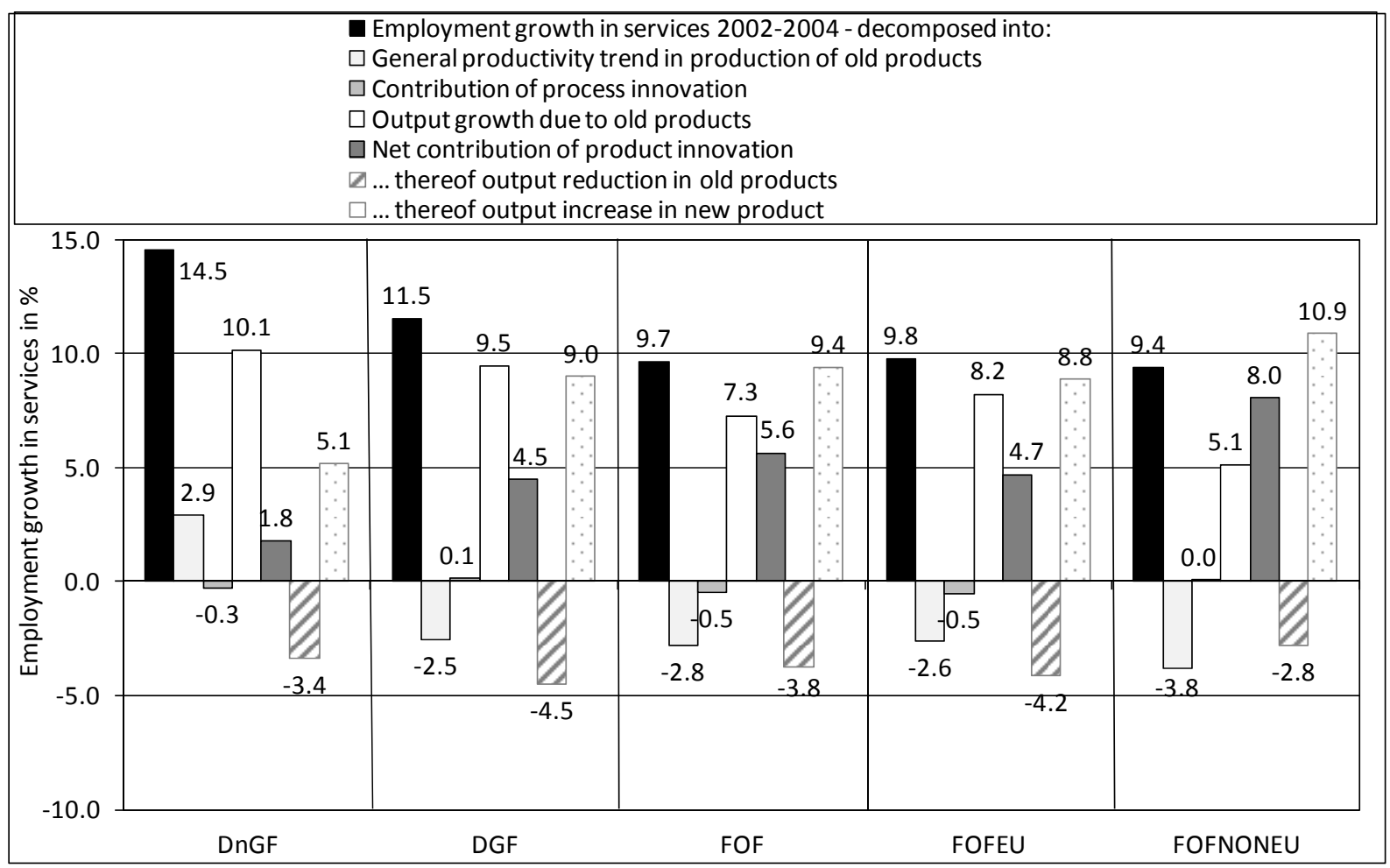

Source: CIS4, Eurostat, own calculation. 
General productivity gains (and thus corresponding labour savings) are smaller in services than in manufacturing. Like in manufacturing, however, FOF benefit more from general productivity gains than DnGF and DGF. But in contrast to manufacturing, it is the group of non-European FOF in services that realize stronger non-innovation related gains in productivity than European FOF. Remember that the econometric analysis revealed that the latter group achieves stronger innovation-related improvements in productivity.

Moreover, old products contribute on average more to employment growth than new products, except for non-European FOF. The importance of demand growth for old products in employment creation is lower for FOF than for DnGF and DGF in services. On the other hand, new products have an even higher absolute and relative contribution to employment growth for both Non-European and European FOF which is in line with H1.

To sum up, the analysis supports $\mathrm{H} 1$ which assumes that FOF experience a higher employment growth from product innovation (except for H1c for FOFNONEU in manufacturing). There is also partly evidence for $\mathrm{H} 2$ in manufacturing. $\mathrm{H} 2$ states that FOF also have a larger employment reduction from process innovation than DnGF and DGF. In services the coefficients of PC go in the expected direction though none of the effects are significant.

Hypothesis H3 states that employment effects in DGF are more similar to the effects we observe in FOF than in DnGF. Econometric results, corroborating that in manufacturing process innovation significantly lowers employment growth in DnGF but not in FOF and DGF, confirm H3. The decomposition of employment growth further shows a very similar picture with respect to each component for FOF and DGF in manufacturing compared to DnGF. The picture that emerges for services is less clear. We observe significantly positive effects for product innovations in all three groups and non-significant results for process innovation. Regarding the decomposition figure 4 shows that DGF are in-between FOF and DnGF. That is, on the one hand the contribution of the general productivity trend innovation is very similar in FOF and DGF whereas we find considerable differences in the output growth due to existing and to a lesser extent also to new products between DGF and DnGF. One explanation that might explain the finding that FOF and DGF are more similar in manufacturing than in services is that the proportion of multinational DGF is larger among manufacturing than service firms. And as set forth in subsection 2.2, multinationality is a key argument that is put forward in this discussion and relates in particular to potential gains from 
product innovation. ${ }^{10}$ For instance, in the German CIS4 60\% of DGF in manufacturing were multinational groups while this share amounts to $37 \%$ in services.

Finally, H4 states that the country of origin of the foreign-owned firm matters for employment creation and destruction. One the one-hand we spot larger productivity gains (displacement effects) from process and product innovation for non-European FOF than for European FOF in manufacturing. The latter group is characterized by larger employment reductions due to non-innovation related productivity gains. The opposite result has been identified for service firms. We therefore find support for H4.

\subsection{Sensitivity analyses}

In this section, we present some further sensitivity analyses to check on the robustness of our results. First, we include variables that measure variations in demand and labour market conditions of the host countries instead of simple country dummies to capture country differences. These conditions presumably have a direct impact on changes in employment, but may also affect how innovation impacts employment growth. As a measure for demand we include Eurostat information on GDP per capita (GDP) in the initial period 2002. ${ }^{11}$ Labour market conditions are proxied by the lagged unemployment rate (UNEMP) and by the lagged OECD indicator on employment protection. Employment protection is measured as the unweighted average of sub-indicators for dismissal of employees on regular contracts and for strictness of regulation on temporary contracts (EMPPROT). The indicator ranges from 0 (least restrictive) to 6 (most restrictive).

Table 6 shows the results for FOF and DGF. The unemployment rate in the host country shows the expected negative sign in all subgroups and is significant in all cases except for FOF in services. With respect to employment protection we do not find a common pattern. In manufacturing, a stronger employment protection leads to a significantly lower employment growth rate in FOF. This effect is also negative but much smaller in magnitude and insignificant for DGF. In services, the coefficient of the employment protection is similar in size for FOF and DGF, but only significant for DGF. GDP is positive but not significant in most subgroups and significantly negative for foreign-owned manufacturing firms. The weak results for GDP may be surprising at first glance. We can rule out multicollinearity problems

\footnotetext{
10 The data set at hand does not include information on whether DGF are a multinational group. But figures from the German CIS4 show that $60 \%$ of DGF in manufacturing are multinational groups while this share amounts to $37 \%$ in services (own calculation).

11 Instead of taking levels, we have also experimented with the GDP growth rate and found similar results.
} 
between GDP and the unemployment rate (correlation: 0.2). We believe that this result mirrors the fact that GDP measures general demand factors while we have already accounted for firm-specific changes in demand for existing and new products which are highly significant. Most importantly, our results with respect to the impact of product and process innovation on employment growth turn out to be rather robust.

Table 6: Sensitivity Analysis I: The role of host country demand and labour conditions

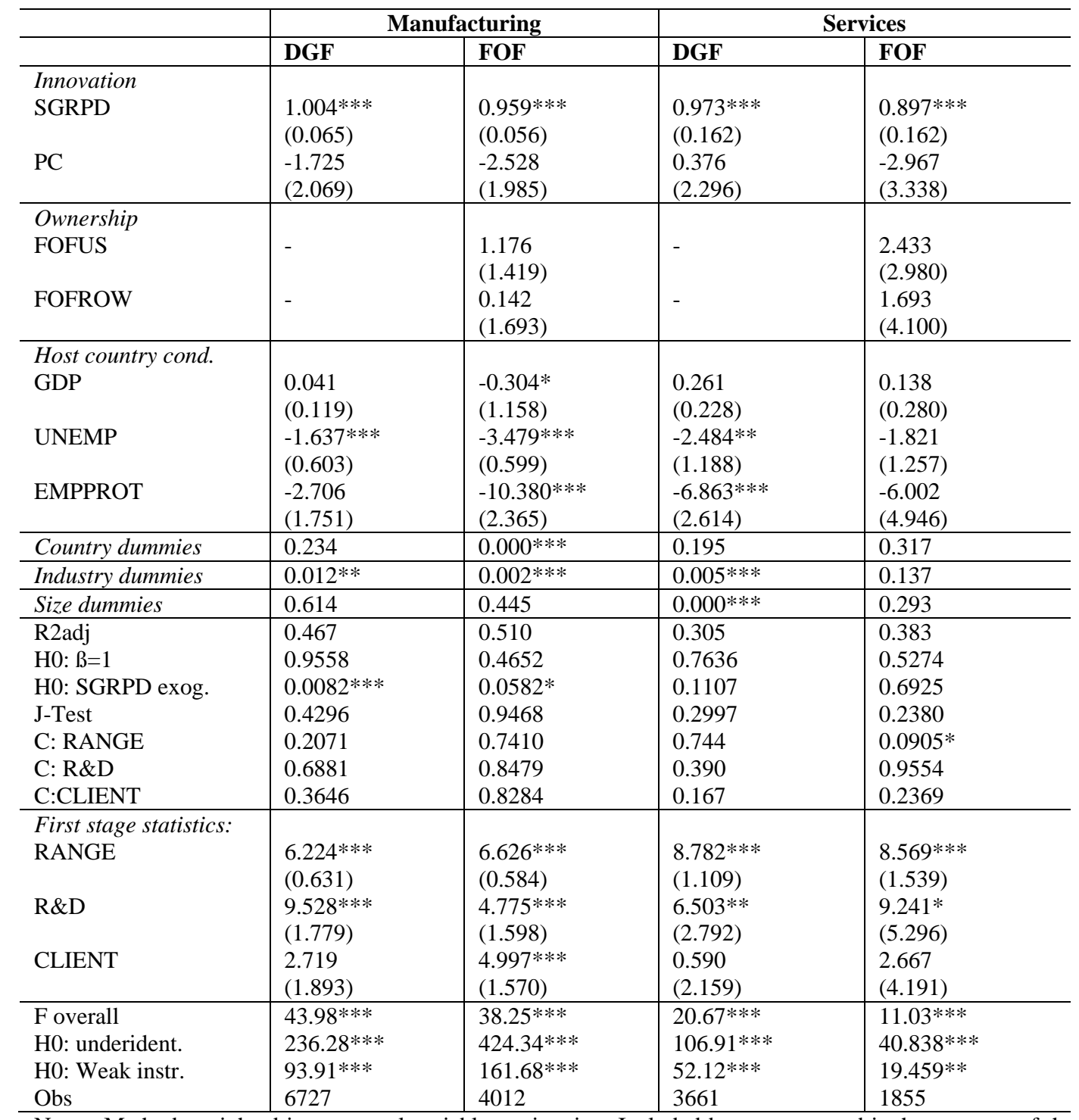

Notes: Method: weighted instrumental variables estimation. Included but not reported is the constant of the regression. For further explanations see Table 3.

Source: CIS 4, Eurostat, own calculation.

Second, we split our sample into West and East European host countries and re-run the regressions. There are considerable differences in the motives of firms to relocate production and innovation activities between these two regions (Stehrer et al., 2012, p. 107). Relocations 
to East European countries are much stronger related to cost saving motives, while West European locations are mainly chosen for access to markets, knowledge and favourable transportation cost. These differences, in turn, might lead to differences in employment creation and destruction as well. For instance, if FOF primarily seek to reduce production costs, they may aim at achieving higher efficiency gains and thus less employment growth from process and product innovations.

Tables 7 and 8 depict results for manufacturing firms. There are two striking results supporting our initial supposition. First, the coefficients of SGRPD significantly differ between FOF located in West and East European host countries. In East Europe the effect is significantly smaller than one, indicating that new products are produced with higher productivity and thus less labour than old products (H1b). Second, the results confirm significant efficiency gains of new production technologies for FOF in East Europe (H2a) but not in West Europe.

Table 7: Sensitivity Analysis II: Effect of innovation on employment growth by ownership and region, manufacturing

\begin{tabular}{|c|c|c|c|c|c|c|}
\hline & West Europe & & & East Europe & & \\
\hline & DnGF & DGF & FOF & DnGF & DGF & FOF \\
\hline $\begin{array}{l}\text { Innovation } \\
\text { SGRPD } \\
\text { PC }\end{array}$ & $\begin{array}{l}1.025 * * * \\
(0.030) \\
-2.086 * * \\
(1.049) \\
\end{array}$ & $\begin{array}{l}0.997 * * * \\
(0.068) \\
-1.734 \\
(2.116) \\
\end{array}$ & $\begin{array}{l}1.020 * * * \\
(0.073) \\
-1.018 \\
(2.165) \\
\end{array}$ & $\begin{array}{l}0.979 * * * \\
(0.026) \\
0.492 \\
(1.597) \\
\end{array}$ & $\begin{array}{l}0.993 * * * \\
(0.076) \\
-7.169 \\
(4.913) \\
\end{array}$ & $\begin{array}{l}0.816^{* * *} \\
(0.061) \\
-6.546^{*} \\
(3.946) \\
\end{array}$ \\
\hline $\begin{array}{l}\text { Ownership } \\
\text { FOFUS } \\
\text { FOFROW }\end{array}$ & 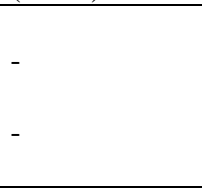 & $\begin{array}{l}- \\
-\end{array}$ & $\begin{array}{l}1.709 \\
(1.477) \\
0.492 \\
(1.728)\end{array}$ & 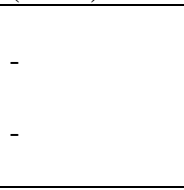 & - & $\begin{array}{l}-1.358 \\
(3.648) \\
0.451 \\
(3.922) \\
\end{array}$ \\
\hline $\begin{array}{l}\text { R2adj } \\
\text { H0: } §=1 \\
\text { H0: SGRPD exog } \\
\text { J-Test } \\
\text { C: RANGE } \\
\text { C: R\&D } \\
\text { C:CLIENT }\end{array}$ & $\begin{array}{l}0.378 \\
0.4212 \\
0.0000^{* * *} \\
0.2905 \\
0.5564 \\
0.1251 \\
0.5448 \\
\end{array}$ & $\begin{array}{l}0.469 \\
0.9673 \\
0.0124^{* *} \\
0.5027 \\
0.2418 \\
0.5692 \\
0.5276 \\
\end{array}$ & $\begin{array}{l}0.520 \\
0.7870 \\
0.0510^{*} \\
0.7784 \\
0.9941 \\
0.5867 \\
0.5839 \\
\end{array}$ & $\begin{array}{l}0.467 \\
0.4227 \\
0.0000^{* * *} \\
0.1473 \\
0.5605 \\
0.1208 \\
0.1423 \\
\end{array}$ & $\begin{array}{l}0.572 \\
0.9291 \\
0.0756 * \\
0.2157 \\
0.0887 \\
0.6151 \\
0.0875 \\
\end{array}$ & $\begin{array}{l}0.537 \\
0.0023 \\
0.7969 \\
0.0436 \\
0.4763 \\
0.0124 \\
0.3038 \\
\end{array}$ \\
\hline $\begin{array}{l}\text { First stage } \\
\text { statistics: } \\
\text { RANGE } \\
\text { R\&D } \\
\text { CLIENT }\end{array}$ & $\begin{array}{l}8.124 * * * \\
(0.479) \\
7.986 * * * \\
(1.487) \\
7.107 * * * \\
(1.158) \\
\end{array}$ & $\begin{array}{l}6.136 * * * \\
(0.650) \\
9.758 * * * \\
(1.850) \\
2.639 \\
(1.968) \\
\end{array}$ & $\begin{array}{l}5.555 * * * \\
(0.639) \\
4.868 * * * \\
(1.720) \\
4.525 * * * \\
(1.656) \\
\end{array}$ & $\begin{array}{l}10.913^{* * *} \\
(0.995) \\
8.859^{* * *} \\
(3.162) \\
14.010^{* * *} \\
(2.506) \\
\end{array}$ & $\begin{array}{l}6.616^{* * *} \\
(1.320) \\
4.786 \\
(2.928) \\
14.353^{* * *} \\
(3.564) \\
\end{array}$ & $\begin{array}{l}11.187^{* * *} \\
(1.103) \\
5.687 * \\
(3.010) \\
6.428^{* *} \\
(3.023) \\
\end{array}$ \\
\hline $\begin{array}{l}\text { F overall } \\
\text { Obs }\end{array}$ & $\begin{array}{l}63.41^{* * *} \\
16651\end{array}$ & $\begin{array}{l}104.47 * * * \\
6213\end{array}$ & $\begin{array}{l}30.22 * * * \\
2974\end{array}$ & $\begin{array}{l}68.33^{* * * *} \\
12153\end{array}$ & $\begin{array}{l}19.71^{* * *} \\
1270\end{array}$ & $\begin{array}{l}23.45^{* * *} \\
1659\end{array}$ \\
\hline
\end{tabular}

Notes: Method: weighted instrumental variables estimation. West Europe comprises DK, ES, FR, GR, IT, LU, NO and PT. East Europe includes BG, CZ, EE, HU, LV, RO, SI and SK. Included in the regression but not reported are industry, country and size dummies and the constant. For further explanations see Table 3.

Source: CIS 4, Eurostat, own calculation. 
Table 8: Sensitivity Analysis II: Decomposition of employment growth by ownership and region, manufacturing

\begin{tabular}{l|c|c|c|c|c|c}
\hline & \multicolumn{3}{|c|}{ West Europe } & \multicolumn{3}{c}{ East Europe } \\
\hline & DnGF & DGF & FOF & DnGF & DGF & FOF \\
\hline Employment growth in manufacturing 2002-2004 & 7.8 & 4.1 & 2.8 & 9.0 & 3.5 & 8.6 \\
General productivity trend in production of old products & -0.3 & -3.7 & -5.0 & 2.9 & -6.5 & -5.6 \\
Contribution of process innovation & -0.3 & -0.3 & -0.1 & 0.0 & -0.7 & -0.7 \\
Output growth due to old products & 6.3 & 4.6 & 4.0 & 3.8 & 4.6 & 9.6 \\
Net contribution of product innovation & 2.1 & 3.5 & 4.0 & 2.3 & 6.0 & 5.3 \\
... thereof output reduction in old products & -4.8 & -7.6 & -8.1 & -5.9 & -11.3 & -8.2 \\
... thereof output increase in new product & 6.9 & 11.0 & 12.1 & 8.3 & 17.3 & 13.5 \\
\hline
\end{tabular}

Source: CIS 4, Eurostat, own calculation.

\section{DISCUSSION AND CONCLUSIONS}

Understanding how foreign-owned and domestically owned firms transform innovation into employment is essential for an evidence-based discussion of the effects of globalisation. This paper disentangled sources of employment growth by ownership, and it particularly investigated the role product and process innovation play for employment.

In the period under consideration, it turned out that employment grew less in foreign-owned companies. The econometric analysis demonstrated that on average foreign-owned firms experience higher employment losses than domestically owned firms due to general productivity increases and in manufacturing also partly due to process innovation. In addition and in contrast to domestic firms, most foreign-owned firms are able to produce new products with a higher efficiency than existing products (except for European FOF in manufacturing). These stronger productivity gains might be worrying as they imply that foreign-owned firms would need to create much more jobs with product innovation and old products to meet the employment growth rate of domestically owned firms. Taking direct and indirect demand effects into account, the decomposition exercise revealed that the net contribution of product innovation to employment is positive, and it is indeed higher for foreign-owned firms than for domestic firms. Together with the positive employment effect stemming from sales growth with old products, this leads in sum to an increase in employment in foreign-owned firms. But it does not reach the employment growth figures for domestically owned firms.

However, this finding does not necessarily mean that countries with a high share of foreignowned firms in the firm population are worse off in terms of employment growth from innovation. First, recent empirical evidence indicates that employment effects of innovation vary with the general economic development. Peters (2008) at the micro level and Lucchese and Pianta (2012) at the industry level demonstrate that the effects from product innovation 
on employment creation are much larger in upswings of the business cycle than in downswings. The latter authors also show that the opposite is true for process innovations and other measures to increase productivity which prevail over product innovation in downswings. The period 2002-2004 was a period of economic downturn. Hence, the weaker performance of foreign-owned firms might be explained by the business cycle. This adds a dynamic perspective to the findings of this paper. If we look at employment fluctuations of foreign-owned and domestically owned firms over the whole business cycle, we may find that foreign-owned firms may create more employment than domestically owned firms in an upswing, but also destroy more in a downswing. Second, our results highlight that foreignowned firms are a more active driver of modernization and structural change. Countries with a high share of foreign-owned firms in the firm population may experience smaller employment growth in the short run. In the long run, however, these countries might enjoy a more favourable economic development due to a higher rate of structural change from product innovation and productivity improvements. With the data at hand, we cannot address these questions and leave them for future research.

A considerable contribution to this long-term growth may come from knowledge spillovers from foreign-owned to domestically owned firms (Keller and Yeaple, 2009). According to Blomström and Kokko (2003), spillovers are the strongest argument as to why countries should try to attract inward investment. Spillovers may spur all four components of employment growth of domestically owned firms discussed in 7.3. In principle, the model for domestic firms could be adapted to attribute the employment creating effects of spillovers from foreign-owned firms. For instance, spillover effects are currently captured in the general productivity trend. Estimating spillovers, however, is beyond the scope of this paper.

The analysis of this paper has some limitations. First, it lacks a long-run perspective as discussed above. The results only take into consideration employment changes up to three years after the innovation. This is sufficient to capture short- and medium-run effects of innovation, for example when a new machine replaces manual labour. However, effects of new products and processes that occur in later periods are excluded. This might concern more indirect employment changes resulting from price effects and demand effects. It seems to be particularly important for innovations new to the market, which may unfold their potential only after years. Given that foreign-owned firms are more innovative, we might underestimate the positive employment impact of product innovation and overestimate the negative impact 
of process innovation. In order to assess long-run employment effects, panel data would be necessary.

Second, the analysis of this paper also miss a part of the 'business stealing effect' when employment growth in one group of firms is at the expense of employment losses of another group of firms. In the model $g_{1}$ includes the business stealing effect that each firm suffers from due to rivals' innovations. However, this is only for surviving firms. Due to data limitations we cannot observe the negative employment effect which emerges when competitors which cannot keep pace with technological change disappear from the market.

Future research should focus on the long-term employment effects of innovation activity of foreign-owned firms on employment and its relationship to the business cycle. The model could be used for another promising line of research which is the assessment of spillover effects from foreign-owned to domestically owned firms. 
APPENDIX

Table A1: CIS4 sample by country

\begin{tabular}{l|l|rr|rr}
\hline \multicolumn{2}{l|}{} & \multicolumn{2}{|c|}{ Manufacturing } & \multicolumn{2}{c}{ Services } \\
\hline Country & Abb. & Number & in \% & Number & in \% \\
\hline Bulgaria & BG & 4,171 & 10.19 & 2,798 & 11.79 \\
Czech Republic & CZ & 2,614 & 6.39 & 1,176 & 4.96 \\
Denmark & DK & 623 & 1.52 & 641 & 2.70 \\
Estonia & EE & 840 & 2.05 & 473 & 1.99 \\
Spain & ES & 8,056 & 19.69 & 2,882 & 12.15 \\
France & FR & 6,379 & 15.59 & 4,811 & 20.28 \\
Greece & GR & 227 & 0.55 & 169 & 0.71 \\
Hungary & HU & 1,717 & 4.20 & 805 & 3.39 \\
Italy & IT & 6,801 & 16.62 & 3,663 & 15.44 \\
Luxembourg & LU & 165 & 0.40 & 311 & 1.31 \\
Latvia & LV & 761 & 1.86 & 447 & 1.88 \\
Norway & NO & 1,532 & 3.74 & 1,135 & 4.78 \\
Portugal & PT & 2,055 & 5.02 & 1,167 & 4.92 \\
Romania & RO & 3,272 & 8.00 & 2,447 & 10.31 \\
Slovenia & SI & 715 & 1.75 & 331 & 1.40 \\
Slovakia & SK & 993 & 2.43 & 470 & 1.98 \\
\hline Total & & 40,921 & 100.00 & 23,726 & 100.00 \\
\hline
\end{tabular}

Notes: Unweighted figures.

Source: CIS 4, Eurostat, own calculation.

Table A2: CIS4 sample by industry

\begin{tabular}{llr|lrr}
\hline \multicolumn{3}{c|}{ Manufacturing } & \multicolumn{3}{c}{ Services } \\
\hline Industry & NACE & in \% & Industry & NACE & in \% \\
\hline Food / beverages / tobacco & $15-16$ & 13.46 & Wholesale & 51 & 40.18 \\
Textile / leather & $17-19$ & 15.41 & Transport / storage / post & $60-63$ & 25.5 \\
Wood / paper / printing & $20-22$ & 12.41 & Telecommunication & 64 & 2.93 \\
Chemicals & $23-24$ & 5.82 & Banks / insurances & $65-67$ & 10.09 \\
Plastic / rubber & 25 & 4.8 & Computer and related activ. & 72 & 9.68 \\
Non-metallic & 26 & 5.82 & Research and development & 73 & 2.67 \\
Basis metals & $27-28$ & 12.66 & Technical services & $74.2+74.3$ & 8.94 \\
Machinery & 29 & 8.21 & & & \\
Electrical & $30-33$ & 9.25 & & & \\
Vehicles & $34-35$ & 5.53 & & & \\
Nec & 36 & 6.64 & & & \\
\hline Total & & 100.00 & & & \\
\hline
\end{tabular}

Notes: Unweighted figures.

Source: CIS 4, Eurostat, own calculation. 
Table A3: Ownership type by country

\begin{tabular}{|c|c|c|c|c|c|}
\hline Country & DnGF & DGF & FOF & FOFEU & $\begin{array}{c}\text { FOF } \\
\text { NON-EU }\end{array}$ \\
\hline \multicolumn{6}{|l|}{ Manufacturing } \\
\hline Bulgaria & 93.1 & 3.1 & 3.7 & 2.8 & 1.0 \\
\hline Czech Republic & 81.2 & 6.8 & 12.0 & 10.2 & 1.8 \\
\hline Denmark & 52.8 & 39.7 & 7.6 & 4.7 & 2.8 \\
\hline Estonia & 72.8 & 15.0 & 12.2 & 10.7 & 1.4 \\
\hline Spain & 88.8 & 7.8 & 3.3 & 2.5 & 0.8 \\
\hline France & 65.6 & 25.3 & 9.1 & 5.8 & 3.3 \\
\hline Greece & 89.2 & 8.7 & 2.1 & 0.7 & 1.4 \\
\hline Hungary & 85.5 & 4.9 & 10.1 & 8.0 & 2.2 \\
\hline Italy & 88.3 & 9.3 & 2.5 & 1.5 & 1.0 \\
\hline Luxembourg & 58.1 & 18.2 & 23.6 & 17.4 & 6.3 \\
\hline Latvia & 94.4 & 2.4 & 3.2 & 2.5 & 0.7 \\
\hline Norway & 57.8 & 34.4 & 7.8 & 6.3 & 1.5 \\
\hline Portugal & 88.4 & 7.5 & 4.1 & 2.9 & 1.2 \\
\hline Romania & 95.1 & 2.2 & 2.6 & 2.1 & 0.6 \\
\hline Slovenia & 67.3 & 26.8 & 5.9 & 5.3 & 0.6 \\
\hline Slovakia & 78.2 & 7.5 & 14.3 & 13.1 & 1.2 \\
\hline Total & 83.1 & 12.0 & 4.9 & 3.4 & 1.5 \\
\hline \multicolumn{6}{|l|}{ Services } \\
\hline Bulgaria & 92.5 & 2.6 & 4.8 & 3.6 & 1.2 \\
\hline Czech Republic & 74.3 & 10.1 & 15.6 & 12.5 & 3.1 \\
\hline Denmark & 43.1 & 38.0 & 18.9 & 10.7 & 8.2 \\
\hline Estonia & 66.6 & 18.6 & 14.8 & 12.9 & 1.9 \\
\hline Spain & 82.9 & 10.6 & 6.5 & 4.6 & 1.9 \\
\hline France & 72.2 & 18.7 & 11.3 & 7.3 & 4.0 \\
\hline Greece & 81.0 & 19.5 & 8.3 & 6.2 & 2.1 \\
\hline Hungary & 79.4 & 6.1 & 12.8 & 10.5 & 2.3 \\
\hline Italy & 41.2 & 14.2 & 6.4 & 4.0 & 2.4 \\
\hline Luxembourg & 84.0 & 16.7 & 42.1 & 32.3 & 9.8 \\
\hline Latvia & 52.1 & 2.8 & 13.2 & 11.4 & 1.8 \\
\hline Norway & 78.6 & 20.0 & 17.9 & 13.8 & 4.1 \\
\hline Portugal & 93.4 & 13.8 & 7.6 & 5.8 & 1.8 \\
\hline Romania & 73.3 & 2.6 & 4.1 & 3.0 & 1.1 \\
\hline Slovenia & 72.6 & 15.9 & 10.8 & 6.7 & 4.2 \\
\hline Slovakia & 100.0 & 7.7 & 19.7 & 17.8 & 1.9 \\
\hline Total & 73.3 & 17.3 & 9.5 & 6.6 & 2.9 \\
\hline
\end{tabular}

Notes: Weighted figures. Weighting factors are provided by Eurostat.

Source: CIS 4, Eurostat, own calculation. 


\section{REFERENCES}

Aghion, P. and P. Howitt (1992), A Model of Growth Through Creative Destruction. Econometrica 60, 323-351.

Barba Navaretti, G. (2004), Host Country Effects: Conceptual Framework and the Evidence, in: Barba Navaretti, G. and A.J. Venables (Eds.), Multinational Firms in the World Economy, Princeton University Press, Princeton and Oxford, 151-182.

Baum, C.F., M.E. Schaffer and S. Stillman (2007), Enhanced Routines for Instrumental Variables/GMM Estimation and Testing, STATA Journal 7, 465-506.

Bellak, C. (2004), How Domestic and Foreign Firms Differ and Why Does It Matter? Journal of Economic Surveys 18, 483-514.

Bellak, C. and M. Pfaffermayr (2000), Why Foreign-Owned Firms are Different: A Conceptual Framework and Empirical Evidence for Austria, HWWA Discussion Paper.

Benavente, J.M. and R. Lauterbach, R. (2007), The Effect of Innovation on Employment, Evidence from Chilean Firms, UNU-MERIT Working Paper, Maastricht.

Blechinger, D., A. Kleinknecht, G. Licht and F. Pfeiffer (1998), The Impact of Innovation on Employment in Europe - An Analysis Using CIS Data, ZEW Dokumentation 98-02, Mannheim.

Blechinger, D. and F. Pfeiffer (1999), Qualifikation, Beschäftigung und technischer Fortschritt. Empirische Evidenz mit den Daten des Mannheimer Innovationspanels. Jahrbücher für Nationalökonomie und Statistik 218, 128-146.

Blomström, M. and A. Kokko (2003), The Economics of Foreign Direct Investment Incentives, NBER Working Paper W9489, Cambridge [Mass.].

Bloom, N. and J. Van Reenen (2010), Why Do Management Practices Differ Across Firms and Countries? Journal of Economic Perspectives 24, 203-224.

Bogliacino, F. and M. Pianta (2010), Innovation and Employment: A Reinvestigation Using Revised Pavitt classes, Research Policy 39, 799-809.

Buch, C.M. and A. Lipponer (2010), Volatile multinationals? Evidence from the Labor Demand of German Firms, Labour Economics 17, 345-353.

Buckley, P.J. (2000), Cross-border Governance in Multinational Enterprises, in: Buckley, P.J. (Ed.), Multinational Firms, Cooperation and Competition in the World Economy, Macmillan Press, Basingstoke, 289-304.

Caves, R. (1996), Multinational Enterprises and Economic Analysis, Cambridge University Press, Cambridge.

Chennells, L. and J. Van Reenen (2002), The Effects of Technical Change on Skills, Wages and Employment: A Survey of the Micro-Econometric Evidence, in: Greenan, N., Y. L'Horty and J. Mairesse (Eds.), Productivity, Inequality, and the Digital Economy: A Transatlantic Perspective, MIT Press, Cambridge [Mass.], 175-224.

Cragg, J.G. and S.G. Donald (1993), Testing Identifiability and Specification in Instrumental Variable Models, Econometric Theory 9, 222-240. 
Dachs, B., B. Ebersberger and H. Lööf (2008), The Innovative Performance of Foreignowned Enterprises in Small Open Economies, Journal of Technology Transfer 33, 393406.

Drejer, I. (2000), Comparing Patterns of Industrial Interdependence in National Systems of Innovation - A Study of Germany, the United Kingdom, Japan and the United States. Economic Systems Research 12, 377-399.

Dunning, J. (1981), International Production and the Multinational Enterprise, Allen and Unwin, London.

Ebersberger, B., H. Lööf and J. Oksanen (2005), Does Foreign Ownership Matter for the Innovation Activities of Finnish Firms?, VTT Working Paper 26, Helsinki.

Entorf, H. and W. Pohlmeier (1990), Employment, Innovation and Export Activity: Evidence from Firm-Level Data, in: Florens, J.-P., M. Ivaldi, J.-J. Laffont and F. Laisney (Eds.), Microeconometrics: Surveys and Applications, Oxford, 394-415.

Evangelista, R. and M. Savona (2003), Innovation, Employment and Skills in Services. Firm and Sectoral Evidence, Structural Change and Economic Dynamics 14, 449-474.

Frenz, M. and G. Ietto-Gillies (2007), Does Multinationality Affect the Propensity to Innovate? An Analysis of the Third UK Community Innovation Survey, International Review of Applied Economics 21, 99-117.

Garcia, A., J. Jaumandreu and C. Rodriguez (2004), Innovation and Jobs: Evidence From Manufacturing Firms, Open Access Publication from Universidad Carlos III de Madrid hdl:10016/5263.

Globerman, S., J.C. Ries and I. Vertinsky (1994), The Economic Performance of Foreign Affiliates in Canada, Canadian Journal of Economics 27, 124-149.

Greenan, N. and D. Guellec (2000), Technological Innovation and Employment Reallocation, Labour 14, 547-590.

Griffith, R. and H. Simpson (2004), Characteristics of Foreign Owned Firms in British Manufacturing, in: NBER (Eds), Seeking a Premier Economy: The Economic Effects of British Economic Reforms, 1980-2000, 147-180.

Gupta, A.K. and V. Govindarajanan (2000), Knowledge Flows Within Multinational Corporations, Strategic Management Journal 21, 473-496.

Hall, B.H., F. Lotti and J. Mairesse (2008), Employment, Innovation, and Productivity: Evidence from Italian Microdata, Industrial Corporate Change 17, 813-839.

Harris, R. and C. Robinson (2003), Foreign Ownership and Productivity in the United Kingdom Estimates for U.K. Manufacturing Using the ARD, Review of Industrial Organization 22, 207-223.

Harrison, R., J. Jaumandreu, J. Mairesse and B. Peters (2008), Does Innovation Stimulate Employment? A Firm-Level Analysis Using Comparable Micro-Data From Four European Countries, NBER Working Paper 14216, Cambridge [Mass.].

Helpman, E., M.J. Melitz and S.R. Yeaple (2004), Export Versus FDI with Heterogeneous Firms, American Economic Review 94, 300-316. 
Keller, W. (2010), International Trade, Foreign Direct Investment, and Technology Spillovers, in: Hall, B.A. and N. Rosenberg, N. (Eds.), Handbook of The Economics of Innovation, Elsevier, Amsterdam, 794-829.

Keller, W. and S.R. Yeaple (2009), Multinational Enterprises, International Trade, and Productivity Growth: Firm-Level Evidence from the United States, Review of Economics and Statistics 91, 821-831.

Kleibergen, F. and R. Paap (2006), Generalized Reduced Rank Tests Using the Singular Value Decomposition, Journal of Econometrics 133, 97-126.

König, H., G. Licht and H. Buscher (1995), Employment, Investment and Innovation at the Firm Level, in: OECD (Ed.), The OECD Jobs Study - Investment, Productivity and Employment, Paris, 67-81.

Lachenmaier, S. and H. Rottmann (2011), Effects of Innovation on Employment: A Dynamic Panel Analysis, International Journal of Industrial Organization 29, 210-220.

Lucchese, M. and M. Pianta (2012), Innovation and Employment in Economic Cycles, Comparative Economic Studies 54, 341-359.

Lundvall, B.-A. (1998). Why Study National Systems and National Styles of Innovation? Technology Analysis \& Strategic Management 10 (4), 407-422.

Marin, A. and S. Sasidharanb (2010), Heterogeneous MNC Subsidiaries and Technological Spillovers: Explaining Positive and Negative Effects in India, Research Policy 39, 12271241.

Markusen, J.R. (2002), Multinational Firms and the Theory of International Trade, MIT Press, Cambridge [Mass.] and London.

Motohashi, K. and Y. Yuan (2010), Productivity Impact of Technology Spillover From Multinationals to Local Firms: Comparing China's Automobile and Electronics Industries, Research Policy 39, 790-798.

O'Mahony, M. and M.P. Timmer (2009), Output, Input and Productivity Measures at the Industry Level: The EU KLEMS Database, Economic Journal 119, F374-F403.

OECD (2005), Oslo Manual. Guidelines for Collecting and Interpreting Innovation Data, Third Edition, Paris.

Oulton, N. (1998), Investment, Capital and Foreign Ownership in UK Manufacturing, NIESR Discussion Papers No 141, London.

Peters, B. (2008), Innovation and Firm Performance - An Empirical Investigation for German Firms, ZEW Economic Studies 38, Heidelberg, New York.

Pianta, M. (2005), Innovation and Employment, in: Fagerberg, J., D.C. Movery and R.R. Nelson (Eds.), The Oxford Handbook of Innovation, Oxford University Press, Oxford, 568-598.

Rottmann, H. and M. Ruschinski (1998), The Labour Demand and the Innovation Behaviour of Firms, Jahrbücher für Nationalökonomie und Statistik 217, 741-752.

Sadowski, B.M. and G. Sadowski-Rasters (2006), On the Innovativeness of Foreign Affiliates: Evidence From Companies in The Netherlands, Research Policy 35, 447-462. 
Scheve, K. and M.J. Slaughter (2004), Economic Insecurity and the Globalization of Production, American Journal of Political Science 48, 662-674.

Smolny, W. (1998), Innovations, Prices and Employment: A Theoretical Model and an Empirical Application for West German Manufacturing Firms, The Journal of Industrial Economics 46, 359-381.

Smolny, W. (2002), Employment Adjustment at the Firm Level. A Theoretical Model and an Empirical Investigation for West German Manufacturing Firms, Labour 16, 65-88.

Smolny, W. and T. Schneeweis (1999), Innovation, Wachstum und Beschäftigung - Eine empirische Untersuchung auf der Basis des ifo Unternehmenspanels, Jahrbücher für Nationalökonomie und Statistik 218, 453-472.

Stehrer, R., M. Borowiecki, B. Dachs, D. Hanzl-Weiss, S. Kinkel, J. Pöschl, M. Sass, T.C. Schmall and A. Szalavetz (2012), Global Value Chains and the EU Industry, Background Report to the 2012 European Competitiveness Report, Vienna.

Stock, J.H. and M. Yogo (2005), Testing for Weak Instruments in Linear IV Regression, in: Stock, J.H. and D.W.K. Andrews (Eds.), Identification and Inference for Econometric Models: Essays in Honor of Thomas J. Rothenberg, Cambridge University Press, New York.

Un, C.A. and A. Cuervo-Cazurra (2008), Do Subsidiaries of Foreign MNEs Invest More in R\&D than Domestic firms? Research Policy 31, 1812-1828.

Van Reenen, J. (1997), Employment and Technological Innovation: Evidence from U.K. Manufacturing Firms, Journal of Labor Economics 15, 255-284.

Vivarelli, M. and M. Pianta (2000), The Employment Impact of Innovation: Evidence and Policy. Routledge.

Williams, C. and S.H. Lee (2009), Resource Allocations, Knowledge Network Characteristics and Entrepreneurial Orientation of Multinational Corporations, Research Policy 38, 1376-1387.

Zanfei, A. (2000), Transnational Firms and the Changing Organisation of Innovative Activities, Cambridge Journal of Economics 24, 515-542. 